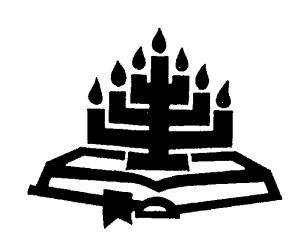

\title{
Die eskatologie van 1 Petrus: hoop en vindikasie vir tydelike en permanente uitlanders
}

\author{
Fika Janse van Rensburg \\ Skool vir Bybelwetenskappe \& Antieke Tale \\ Potchefstroomkampus \\ Noordwes-Universiteit \\ POTCHEFSTROOM \\ E-pos: fika.jansevanrensburg@nwu.ac.za
}

\section{Abstract \\ The eschatology of 1 Peter: hope and vindication for visiting and resident strangers}

The addressees of 1 Peter were living in an unfriendly environment. They were aliens and strangers, probably not only because of their Christian faith, but mainly because they were not citizens of the areas they lived in. Their alien status contributed considerably to their special situation, and this is the context within which the eschatology of 1 Peter is constructed. This article presents a working definition of eschatology. Then it constructs the life situation of the addressees. The eschatological utterances are identified and categorised, and the argument of 1 Peter is briefly constructed. The eschatological utterances are then interpreted. Finally the eschatology of 1 Peter is concluded and summarised.

\section{Opsomming}

Die eskatologie van 1 Petrus: hoop en vindikasie vir tydelike en permanente uitlanders

Die geadresseerdes van 1 Petrus het in 'n onvriendelike omgewing geleef. Hulle was uitlanders, moontlik nie net oor hulle Christelike geloof nie, maar hoofsaaklik omdat hulle nie burgers was van die gebiede waar hulle gewoon het nie. Hulle status as uitlanders het aansienlik bygedra tot hulle unieke situasie, en dit is die konteks waarbinne die eskatalogie van 1 Petrus gekonstrueer word. Hierdie artikel bied 'n werksdefinisie van eskatologie. Daarna word die lewensomstandighede van die geadresseerdes gekonstrueer. Die eskatologiese uitsprake word geï- 
dentifiseer en gekategoriseer en die argument van 1 Petrus word kortliks gekonstrueer. Die eskatologiese uitsprake word vervolgens geïnterpreteer en laastens word 'n gevolgtrekking oor die eskatologie van 1 Petrus gemaak.

\section{Inleiding}

Aune (1996:594) voer aan dat die term eskatologie in die hedendaagse tyd gebruik word "to refer to the whole constellation of beliefs and conceptions about the end of history and the transformation of the world which particularly characterised early Judaism, and early Christianity, and Islam, i.e., cosmic eschatology". Hy stel dit dat die sentrale fokusse van hierdie oortuigings die oordeel oor sondaars en die redding van die gelowiges is. Hy (Aune, 1996:594) voeg egter by, die eskatologie "is a mode of understanding the complete realization of salvation as a future event or series of events which are, nevertheless, somehow linked to the present".

Thomas (1997:53-60) herdefinieer eskatologie as die leerstelling van "ultimate" gebeure eerder as "last things". "Ultimate reality is not just what will transpire at the end of time, but that which God apparently has always sought to make a present reality" (Thomas, 1997:55). ${ }^{1}$ Die resultate van my navorsing oor die eskatologie van 1 Petrus het my oortuig om aspekte van hierdie siening van eskatologie te deel.

Uit my navorsing het dit verder duidelik geword dat die outeur verstaan het dat hy en sy geadresseerdes reeds in die eindtyd leef. Hy sien dus hulle huidige verlossing in Christus as 'n reeds-gerealiseerde eindtydwerklikheid. Die argument van Beale (1997:17-18) dat "the apostles understood eschatology not merely as futurology but as a mindset for understanding the present within the climaxing context of redemptive history" is hiervolgens geldig ook vir 1 Petrus.

In my benadering gebruik ek bewustelik bibliologiese kategorieë en konsepte, in teenstelling met kategorieë en konsepte uit die Sistematiese Teologie. Met die oog hierop konstrueer ek voorts die lewensomstandighede van die geadresseerdes. Dan word die eska-

1 Thomas pas hierdie benadering toe op heiligheid, en hy toon aan dat God regdeur die Skrif aandui dat Hy onder ' $n$ heilige volk op 'n heilige plek wil woon. Hy argumenteer dat die eskatologiese oproep is om 'n spieëlbeeld van God in sy heiligheid te word. Hy (Thomas, 1997:55) betoog teen 'n temporale/ kronologiese siening van eskatologie ten gunste van 'n ruimtelike en kosmologiese siening. Só verstaan hy ă $\nu \omega \theta \in \nu$ in Johannes 3 nie as 'n verwysing na wedergeboorte nie, maar na "van Bo af gebore word". 
tologiese uitsprake geïdentifiseer en gekategoriseer en die argument van 1 Petrus kortliks gekonstrueer. Die eskatologiese uitsprake word daarna geïnterpreteer en, laastens, word 'n gevolgtrekking oor die eskatologie van 1 Petrus gemaak.

\section{Die lewensomstandighede van die geadresseerdes}

Die doel van hierdie konstruksie van die sosio-historiese konteks van die geadresseerdes van 1 Petrus is om 'n verwysingsraamwerk vir die eskatologiese analise van die brief daar te stel. Hierdie konstruksie is gepubliseer in Van Rensburg (2006:475-481). ${ }^{2}$ Dit kom op die volgende neer:

Die etikettering van die geadresseerdes ${ }^{3}$ as $\pi \alpha \rho \in \pi \iota \delta \eta \dot{\mu o \iota s}$

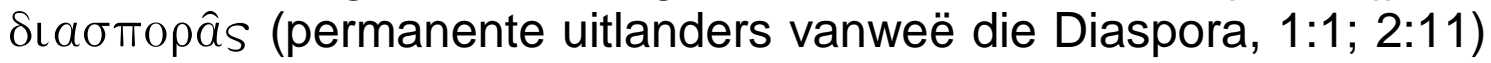
en тápoเкo (tydelike uitlanders, 2:11) verwys nie slegs na 'n metafories-figuurlike status van Christene as "vreemdeling in die wêreld" omdat hulle "burgers van die hemel" is nie. 4 Die geadresseerdes was, reeds voor hulle bekering tot die Christelike godsdiens, "tydelike en permanente uitlanders" in die letterlike sosiaalpolitieke sin van die woord.

Daar is egter, behalwe vir die feit dat hulle uitlanders in die letterlike sosiaal-politieke sin van die woord was, 'n tweede vlak waarop hulle (of ten minste sommiges van hulle) $\pi \alpha \rho \in \pi \iota \delta \eta ́ \mu o ~(\delta \iota a \sigma \pi о \rho \hat{s}$ ) en та́pоเко was. Dit is die feit dat hulle bekeerlinge en

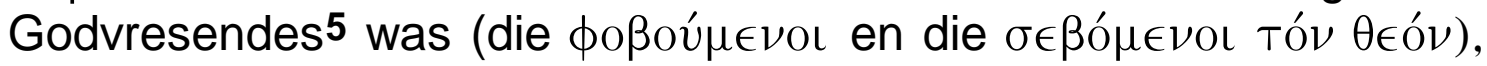
soos Van Unnik (1980a:72-74) oortuigend aanvoer. Die etikettering van die geadresseerdes

as

2 Die metode wat in hierdie konstruksie gebruik word, is die sosio-historiese benadering, verryk met fasette van die sosio-wetenskaplike benadering, soos beskryf deur Garrett (1992:90). Vergelyk Van Rensburg (2000:564-582) vir 'n definiëring van hierdie metode.

3 Verskillende vakkundiges het die stand van navorsing oor die identiteit en omstandighede van die geadresseerdes van 1 Petrus genoegsaam ondersoek, waarvan Goppelt (1978:161-177), Achtemeier (1996:50-58) en veral Feldmeier (1992) die omvattendste is. Vergelyk ook die meer onlangse bydrae deur Seland (2005).

$4 \quad$ Elliott (1981:32; 1996:273) betoog oortuigend teen so 'n vergeesteliking van та́polкo in 1 Petrus. Hierdie vergeesteliking word nie ondersteun deur die sosiale bewustheid wat duidelik blyk uit die gebruik van hierdie terme in vroeë Christelike en apokaliptiese Joodse geskrifte nie.

5 Teenoor Richard (1986:123), wat van mening is dat die geadresseerdes bloot heidense Christene was. 


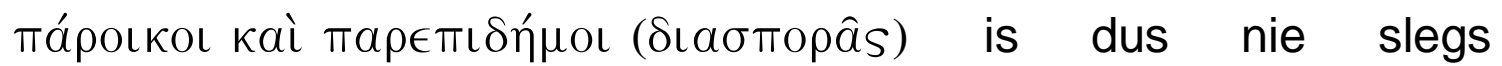
beskrywend van hulle sosiale posisie nie, maar dit dui ook hulle vorige status as Godvresendes aan.

Die outeur van 1 Petrus sluit by hierdie betekenis van mápoเкoเ

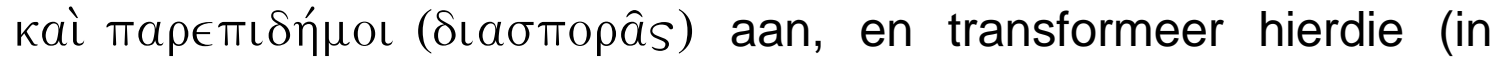
sommige opsigte) beledigende titel tot ' $n$ trotse selfidentifikasie deur dit 'n dieper en spesifiek teologies-positiewe betekenis te gee. Aan die een kant vorm dit deel van die oorname van die eretitels van die Ou-Testamentiese volk van God, en aan die ander kant is hierdie titel tot 'n trotse selfidentifikasie omvorm wat op sy eie bene staan (vgl. Feldmeier, 1992:104).

Die geadresseerdes word as "permanente en tydelike uitlanders" aangedui $(1: 1,17 ; 2: 11)$, maar die brief gee geen uitdruklike oorsaak vir hierdie "uitlander-status" van die geadresseerdes nie. Dit is onwaarskynlik dat amptelike vervolging die oorsaak was. ${ }^{6}$ Die agtergrond blyk eerder die sosiaal-politieke status van die Christelike groepe binne die Diaspora te wees, hulle daaglikse verhouding met Jode en ander nie-Christene, die struikelblokke wat hulle, as "permanente en tydelike uitlanders" daagliks in die gesig moes staar. Hulle swaarkry is dus waarskynlik nie deur amptelike vervolging veroorsaak nie, maar deur spontane plaaslike sosiale verstoting (Balch, 1981:95;7 Elliott, 1976:252; 1986:74; Van Unnik, 1980a:79-80;8 1980b:113, 116; en vgl. ook Moule, 1956-1957:1-11).

Die swaarkry is grootliks binne die kleiner sirkel van die huishouding ervaar. Die pater familias het meerendeels volle gesag oor sy vrou/ vroue, kinders, diensknegte en slawe gehad (vgl. 1 Pet. 3:1). In ge-

6 Teenoor Beare (1970:188), vergelyk Elliott (1976:251-252) en Richard (1986:126) vir 'n goeie opsomming en verwerping van die standpunt dat amptelike vervolging die oorsaak was.

$7 \quad$ Balch (1981:95) is baie spesifiek in sy teenargument: "Rather, certain slaves and wives converted to Christianity; therefore, persons in Roman society reacted by accusing them of being immoral, perhaps seditious, and certainly insubordinate".

Van Unnik (1980a:79-80) sê:

... nowhere do we read that they suffered from the pagan authorities. ... We think of the pagan surroundings and the persecution which might have arisen there, but we read nothing about that either. Is it not more obvious to think about persecution by the Synagogue? ... That is why Christ, who Himself underwent betrayal and death at the hands of the Jews, can be an example to them (chapter ii and iii). This too fits perfectly into the picture that we get in Acts of the earliest mission. There, again and again, it is the Jews who resist and slander Paul and his companions (see Acts xiii 50; xiv 19; xvii 5, 13). 
valle waar die pater familias nie die Christelike godsdiens aangeneem het toe enige ander lid van die huishouding dit wel gedoen het nie, kon dit tot erge diskriminasie teen hierdie nuwe Christen lei.

Die outeur gebruik die brief om die geadresseerdes te oortuig van hulle status as verlostes voor God, dat God uit liefde na hulle omsien, en dat Christus in hulle plek gely het, en van Christus se huidige heerlikheid en absolute mag. Hy spoor hulle aan tot 'n "goeie"

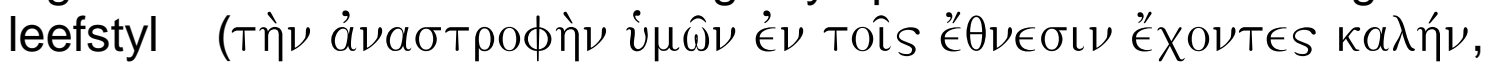

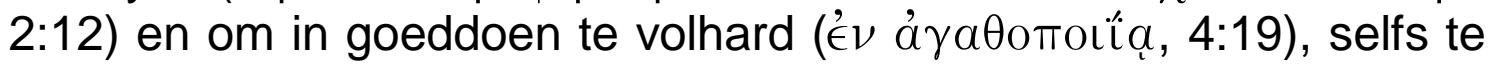
midde en ten spyte van hulle eie swaarkry. Op hierdie manier moes hulle opleef tot hulle status as persone van wie gesê word dat God

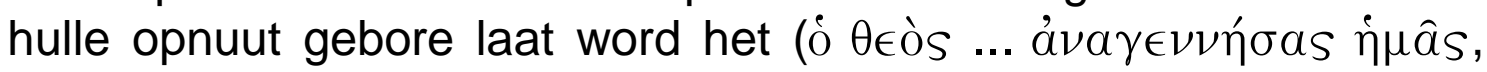
$1: 3)$.

Hierdie konstruksie van die lewensomstandighede van die geadresseerdes in 1 Petrus het 'n impak op die konstruksie van die eskatologie van die brief. Die eskatologiese uitsprake in 1 Petrus kan nou bepaal en gekategoriseer word.

\section{Die eskatologiese uitsprake geïdentifiseer en gekategoriseer}

Die eskatologiese uitsprake in 1 Petrus kan op verskillende wyses geïdentifiseer en gekategoriseer word. In die identifisering en kategorisering wat hier gedoen word, word bibliologiese konsepte en kategorieë berekend gebruik, en sistematies-teologiese konsepte en kategorieë word vermy.

Die identifikasie van eskatologiese uitsprake het 31 voorkomste van 17 verskillende woorde/frases opgelewer. 'n Kategorisering van hierdie eskatologiese uitsprake het die volgende matriks opgelewer:

\section{1 'n Bewustheid van 'n huidige en 'n toekomstige bedeling}

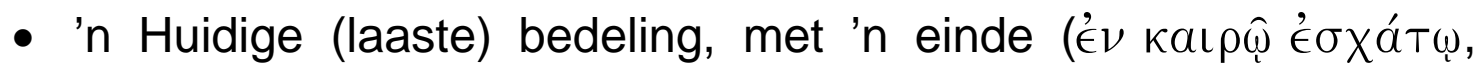

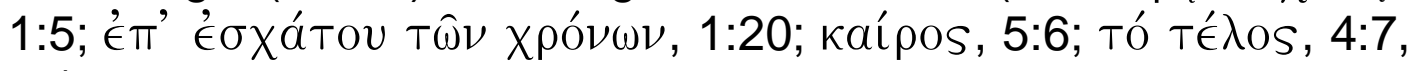
17)

- 'n Volgende bedeling, skynbaar sonder 'n einde (ò alís, 1:25; 4:11; 5:11; aíúvıos, 5:10) 


\section{2 'n Huidige werklikheid, met die verwagting van volle vervulling in die toekoms}

- Die verskyning en/of openbaring van verlossing/Jesus Christus/ Christus se heerlikheid (ảmoкá $\lambda v \psi ı s, 1: 5,7,13 ; 4: 13$; 5:1; $\phi \alpha \nu \in \rho \omega \theta \in \hat{\imath} s, 5: 4)$

- Hoop: 'n sekerheid oor die toekomstige vervulling van 'n huidige

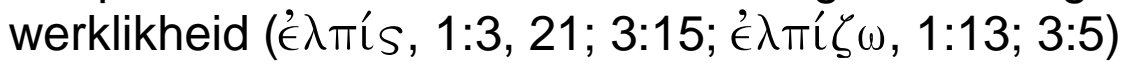

- Verlossing as 'n huidige werklikheid, maar wat nog "voltooi" moet

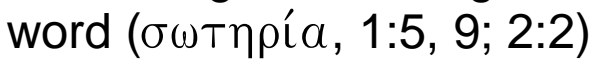

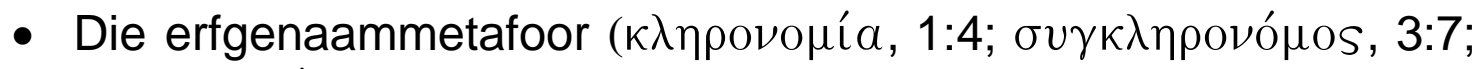

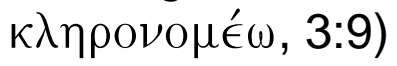

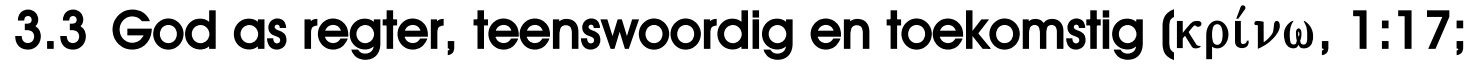

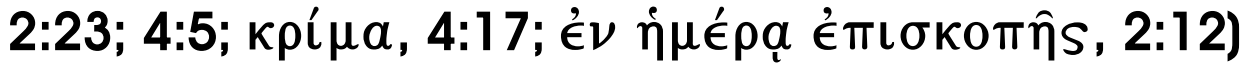

Voor die interpretasie van die eskatologiese uitsprake, is dit nodig om die argument van 1 Petrus te konstrueer en om vas te stel hoe hierdie eskatologiese uitsprake binne die gekonstrueerde argument funksioneer.

\section{Die argument van 1 Petrus}

Ek neem as verwysingsraamwerk vir die interpretasie van die eskatologiese uitsprake die argument van 1 Petrus wat ek in 'n 2006artikel (Van Rensburg, 2006:481-488; vgl. Van Rensburg, 1992:2641) voorgestel het. Volgens hierdie konstruksie van die argument is die basiese stelling in 1 Petrus dat die Vader die geadresseerdes

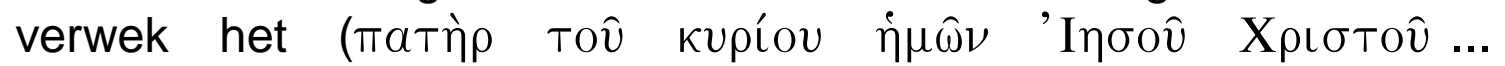

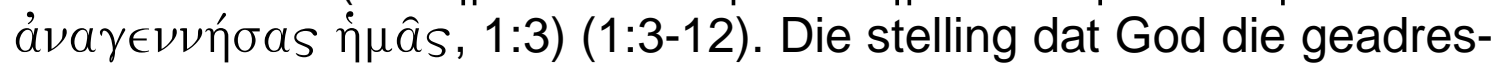
seerdes nuut verwek het, funksioneer as die basis vir vier gevolgtrekkings, aangebied as vier oproepe:

- Vestig jou hoop volledig op die genade, en wees daarom heilig $(1: 13-25)$

- Die plig van 'n "nuwe" kind van God om individueel sowel as saam met medegelowiges te groei (2:1-10)

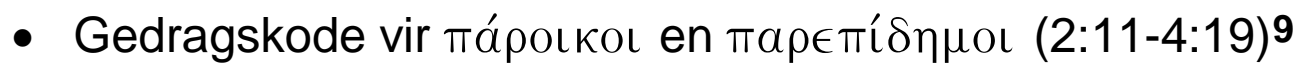

9 Hierdie derde gevolgtrekking is verdeel in die volgende onderafdelings: Die basiese oproep (2:11-12), die gedragskode vir die verhouding met politieke owerhede (2:13-17), met werkgewers (2:18-25), met die huweliksmaat (3:1-7), 
- Gedragskode binne die kerk (5:1-11)

Hierdie konstruksie van die argument van 1 Petrus, en spesifiek die samehang tussen die briefopening (1:3-12) en die inhoud van die brief, kan op die volgende wyse voorgestel word:

\section{Sinopsis van die argument van 1 Petrus}

\section{Briefopskrif}

\section{1:1-2: Outeur, geadresseerdes en groet}

\section{Briefopening}

1:3-12: Aan God, die Vader van ons Here Jesus Christus, kom al die lof toe! In sy groot ontferming het Hy ons nuut-verwek

Vier gevolglike oproepe (basis: "het Hy ons nuut-verwek")

Oproep 1: 1:13-25: Vestig julle hoop volkome op die genade, en wees daarom heilig

Oproep 2: 2:1-10: Die plig van 'n persoon wat nuut-verwek is deur God en wat weergebore is, om geestelik te groei, sowel persoonlik as gesamentlik

Oproep 3: 2:11-4:19: Gedragskode vir uitlanders

2:11-12: Die basiese oproep

2:13-17: Verhouding met politieke owerhede

2:18-25: Verhouding met werkgewers

3:1-7: $\quad$ Verhouding met huweliksmaat

3: 8-12: Verhouding met naaste in die algemeen

3:13-4:19: Houding teenoor en reaksie op veronregting

Oproep 4: 5:1-11: Gedragskode binne die kerk

\section{Briefslot}

5:12-14: Konklusie: Doel, groetwense, briefslot

met die naaste in die algemeen (3:8-12), en vir die houding teenoor en reaksie op veronregting (3:13-4:19). 
Uit die 31 eskatologiese uitsprake is sewe in die briefopening (1 Pet. 1:3-12), 10 en ses in Oproep 1 (1 Pet. 1:13-25). ${ }^{11}$ Dit beteken dat byna $50 \%$ van die eskatologiese uitsprake in hoofstuk 1 van die brief voorkom. In Oproep 2 (1 Pet. 2:1-10) is daar slegs een voorkoms

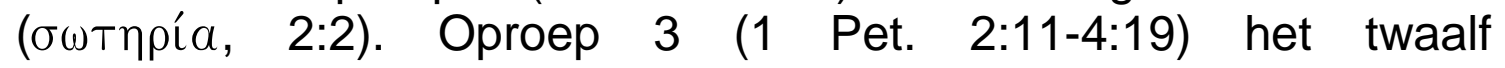
voorkomste, 12 en Oproep 4 (1 Pet. 5:1-11) het vyf. 13

Die twaalf voorkomste in die derde oproep (2:11-4:19) is op die volgende wyse tussen die verskillende onderafdelings versprei: een

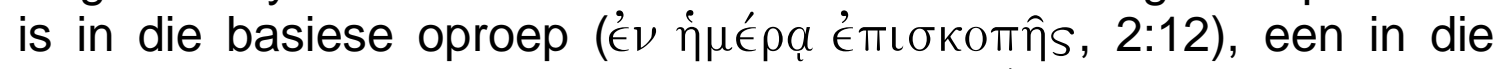

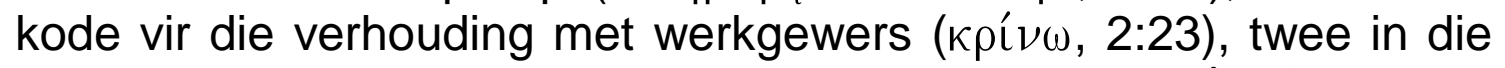

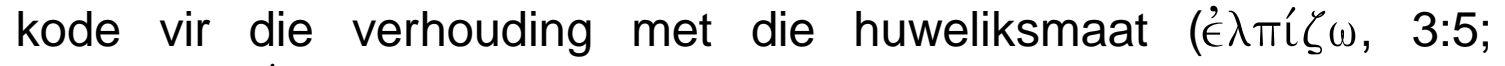
$\sigma v \gamma \kappa \lambda \eta \rho о \nu o ́ \mu o s, ~ 3: 7)$ en een in die kode vir die verhouding met die naaste in die algemeen ( $\kappa \lambda \eta \rho о \nu о \mu \epsilon ́ \omega, 3: 9)$.

My interpretasie van die interverhouding tussen die onderafdelings 3:13-4:19 en die kode vir die houding teenoor en die reaksie op verontregting kan op die volgende wyse voorgestel word:

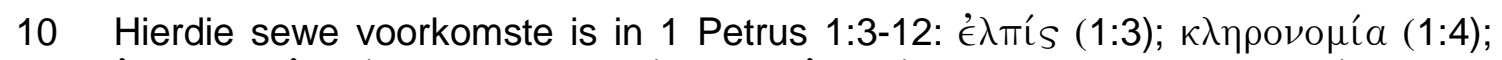

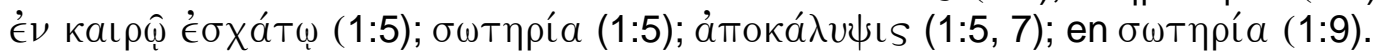

11 Hierdie ses voorkomste in 1 Petrus 1:13-25 is: ámокáduభıs (1:13);

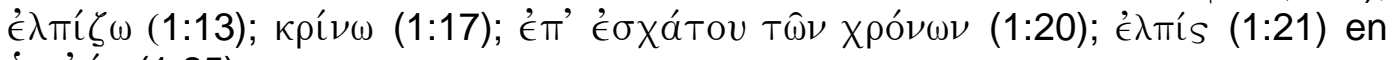
ò aíuv (1:25).

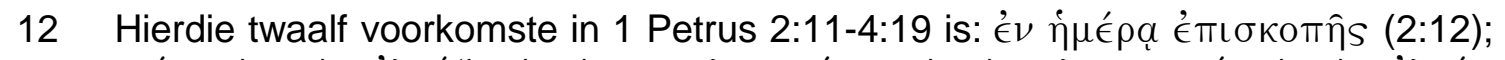

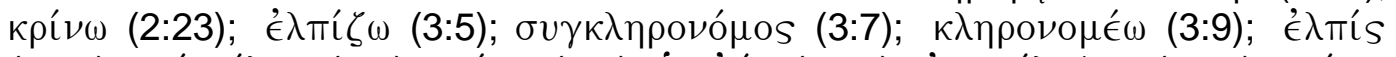

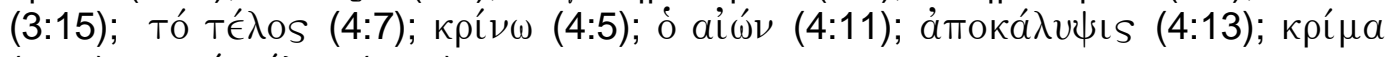

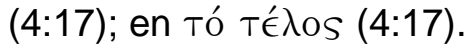

13 Hierdie vyf voorkomste in 1 Petrus 5:1-11 is: ámoкá $\chi \psi \psi ı s ~(5: 1)$; $\phi a \nu \in \rho \omega \theta \in \hat{\imath}$ (5:4); кaípos (5:6); aíúvıos (5:10); en ó aíúv (5:11). 


\section{Die derde oproep (2:11-12) toegepas op die houding teenoor en die reaksie op verontregting}

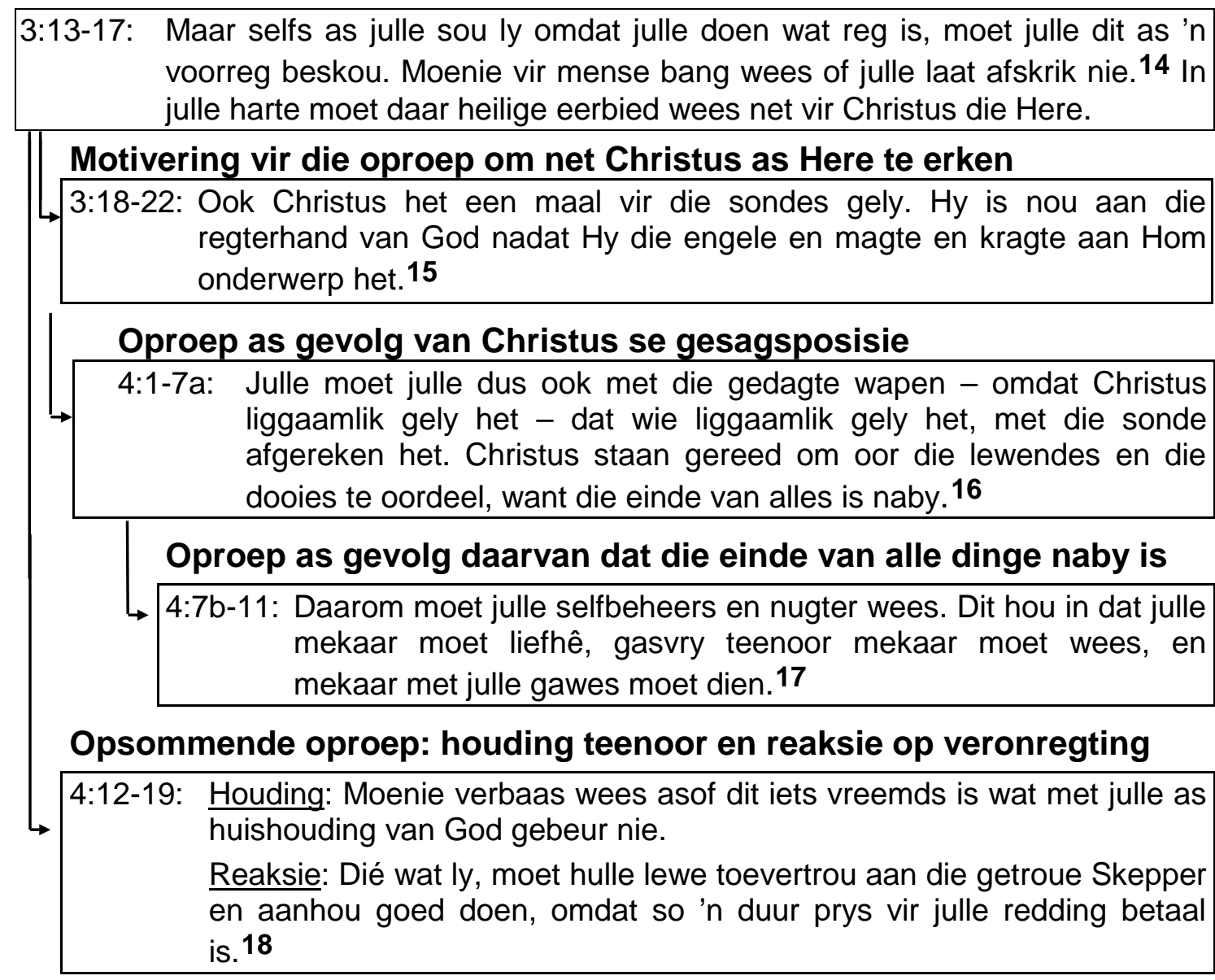

14 Die begin van die vyfde oproep binne die gedeelte 2:11-4:19 word gemerk deur die кaí in 3:13, wat 3:13 met die gevolgtrekkende Tò $\delta \hat{~}$ Té $\lambda$ os in 3:8 koördineer. Die vyfde oproep sluit die geheel van 3:13-4:19 in, en bestaan uit vyf onderafdelings: 3:13-17; 3:18-22; 4:1-7a; 4:7b-11; en 4:12-19.

15 In 3:18 merk ÖT $\mathrm{l}^{\mathrm{b}}$ 3:18-22 as "Rede" in 'n "Rede" $\leftrightarrow$ "Gevolg"-verhouding met 3:13-17; vergelyk Louw en Nida (1988, 1:781).

16 In 4:1 merk oûv $\nu^{a}$ 4:1-7a as "Gevolg" in 'n "Rede" $\leftrightarrow$ "Gevolg"-verhouding met 3:18-22, wat stel dat Christus vir ons sondes gely het; vergelyk Louw \& Nida $(1988,1: 783,812,794)$. Die rá $\rho$ merk hierdie sin as "Rede" in 'n "Rede" $\leftrightarrow$ "Gevolg"-verhouding met 4:5, waar dit gestel word dat selfs die dooies geoordeel sal word; vergelyk Louw \& Nida $(1988,1: 780)$ en Denniston (1966:60) in 4:6. Maar 4:6 word nie as die begin van 'n nuwe perikoop geïnterpreteer nie; dit is eerder die voorlaaste gedeelte van die perikoop 4:1-7a. Dieselfde geld vir die $\delta \epsilon^{a}$ in 4:7a; vergelyk Louw en Nida $(1988,1: 790,789,794)$. Dit merk 4:7a as "Rede" in 'n "Rede" $\leftrightarrow$ "Gevolg"-verhouding met 4:5, wat stel dat Christus gereed is om te oordeel. Maar 4:7a word egter nie as die begin van 'n nuwe perikoop geïnterpreteer nie, maar as die laaste deel van die perikoop 4:1-7a.

17 Die oû $\nu^{\mathrm{a}}$ in 4:7b merk 4:7b-11 as "Gevolg" in 'n "Rede" $\leftrightarrow$ "Gevolg"-verhouding met 5:6-7a, wat stel dat Christus gereed is om te oordeel aangesien die einde van alle dinge naby is; vergelyk Louw en Nida (1988, 1:783, 812, 794).

18 In 4:12 word die asyndeton geïnterpreteer as iets wat die gedeelte 4:12-19 merk as "Resultaat" in 'n "Rede" $\leftrightarrow$ "Resultaat"-verhouding met 3:13-17. 
Sewe van die eskatologiese uitsprake kom voor in die kode vir die houding teenoor en die reaksie op veronregting (1 Pet. 3:13-4:19). ${ }^{19}$

Die konsentrasie eskatologiese uitsprake in sekere dele van die brief is opvallend, en is op sig self 'n wyser na die aard van die eskatologie van 1 Petrus.

\section{Die eskatologiese uitsprake geïnterpreteer}

\section{1 'n Bewustheid van 'n huidige en 'n toekomstige bedeling}

Petrus toon eerstens 'n bewustheid van 'n (finale) huidige en 'n toekomstige (eindelose) bedeling, met ' $n$ begin en 'n einde vir die huidige bedeling, en 'n begin vir die toekomstige bedeling.

\subsection{1 'n Huidige (laaste) bedeling, met 'n einde}

Die outeur se bewustheid van 'n huidige bedeling word bewys deur

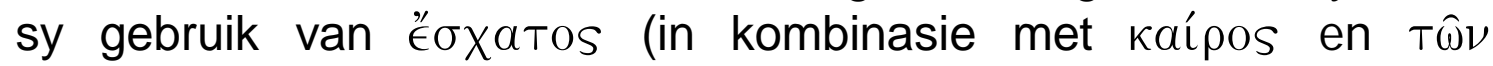

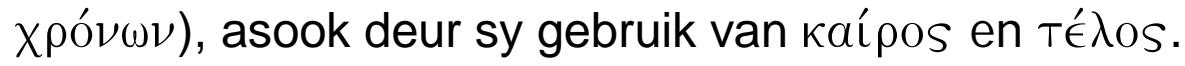

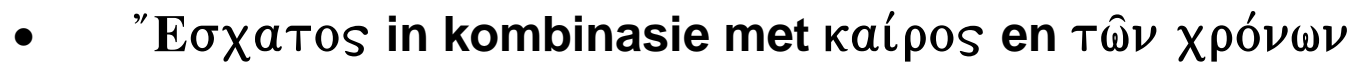

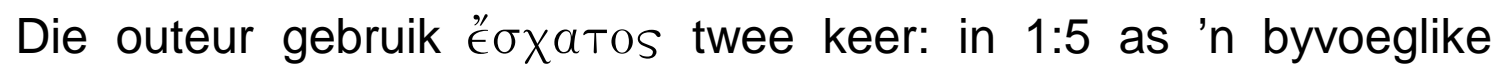

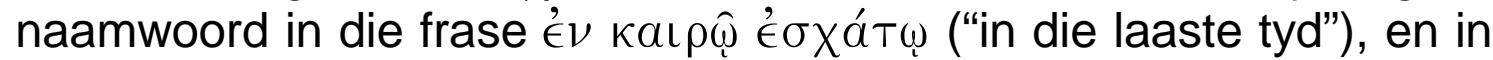
$1: 20$ as 'n substantiewe byvoeglike naamwoord in die frase

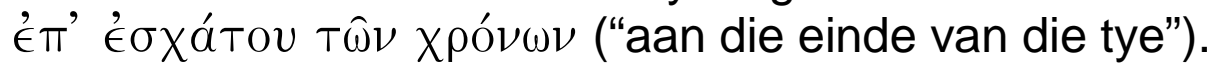

In $1: 20$ is die verwysing na die huidige bedeling: die frase

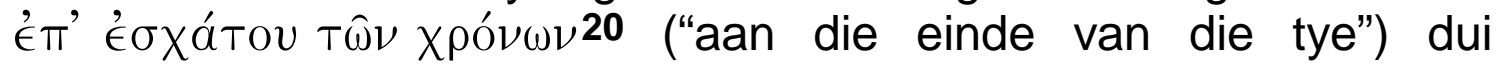

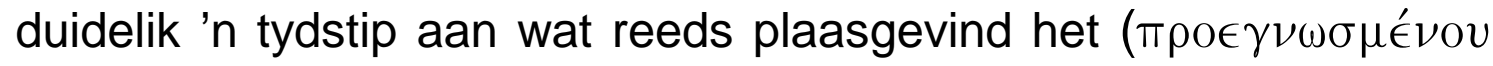

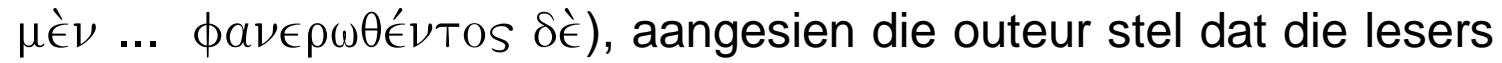
reeds voordeel getrek het uit die feit dat Christus geopenbaar is (vgl. Parker, 1994:27-28):

19 Hierdie sewe voorkomste in 1 Petrus 3:13-4:19 is: é $\lambda$ mís (3:15); Tó Té $\lambda$ os (4:7);

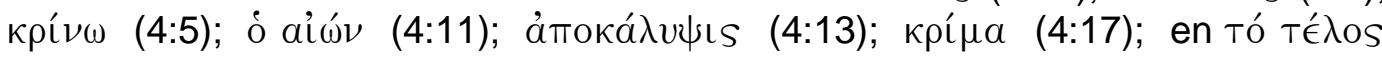
(4:17).

20 Louw en Nida (1996: subdomein 67.78) gee die volgende definisie van hierdie betekenis van xpóvos "an indefinite unit of time (the actual extent of time being determined by the context) - 'time, period of time'". Subdomein 67.78 is deel van die groep subdomeine 67.65-67.72, deur Louw en Nida getipeer as "[a] point of time with reference to duration of time: beginning, end". 
Daar is geen aanduiding of die toekomstige kaípos verwys na die einde van die bedeling of slegs onbepaald na die toekoms nie. In die geval van die ander twee gebruike van kaípos in 1 Petrus, naamlik in $1: 1124$ en $4: 17,25$ is die verwysing gelyktydig na sowel die begin as die einde van die huidige bedeling. Dieselfde kan daarom afgelei word rakende 5:6.

\section{- Té $\quad$ os, ensovoorts}

In 1 Petrus word Té ${ }_{0}$, ensovoorts gebruik in 1:9, 1:13, 3:8, 4:7 en 4:17. Hiervan is die gebruik in 4:7 en 4:17 tersaaklik:26

Die verwysing Tó Té $\lambda_{\text {OS }} \mathbf{2 7}$ in 4:7 en 4:17 is 'n tydstip in die toekoms wat die einde van die huidige bedeling aandui:

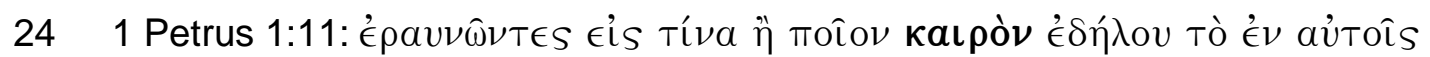
$\pi \nu \in \hat{v} \mu \alpha$ X $\mu \in T a ̀$ Tav̂Ta $\delta o ́ \xi a \tilde{s}$. ("Die Gees van Christus wat in hulle was, het vooruit verkondig dat Christus moet ly en daarna verheerlik sal word, en hulle het probeer, naspeur wat die tyd en die omstandighede sou wees wat die Gees bedoel het." 1983-vertaling.)

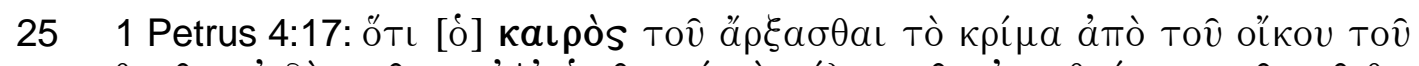

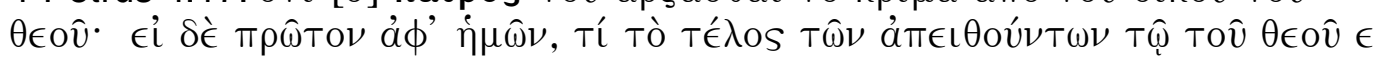
va $\gamma \gamma \in \lambda i ́ \omega$. ("Die tyd vir die oordeel het aangebreek; dit begin by die huis van God. En as ook ons geoordeel word, en dit is nog maar die begin, wat sal die uiteinde dan wees van hulle wat nie na die evangelie van God wou luister nie?" 1983-vertaling.)

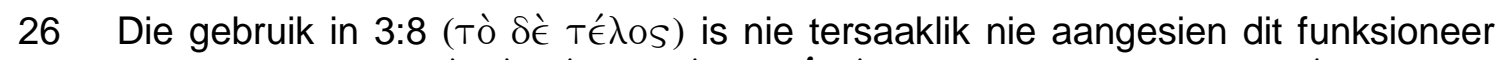

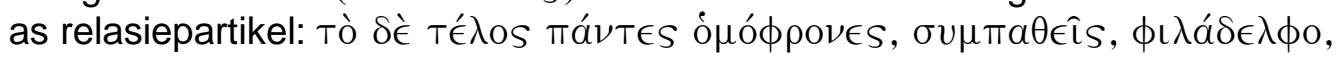
$\epsilon \hat{\cup} \sigma \pi \lambda a \gamma \times \nu 0, \tau a \pi \epsilon \iota \nu{ }^{\prime} \phi \rho O \nu \in S$. ("Ten slotte, wees almal eensgesind, medelydend, liefdevol, goedhartig, nederig". 1983-vertaling.) In 1:13 word $\tau \in \lambda \in \epsilon^{\prime} \omega S$ as bywoord gebruik om die volgende aan te dui: "a degree of completeness, with the possible implication of purpose or result", waarvoor Louw en Nida (1996: subdomein 78.47) die volgende as vertaalmoontlikhede voorstel:

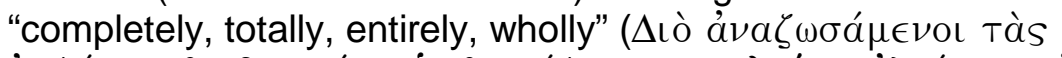

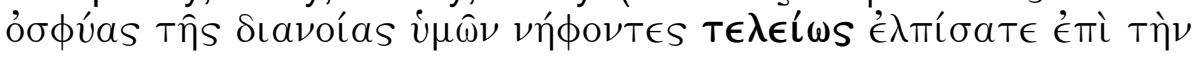

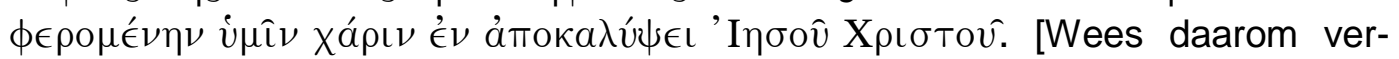
standelik wakker en nugter, en vestig julle hoop volkome op die genade wat julle deel sal word by die wederkoms van Jesus Christus."]) In 1:9 word té $\lambda$ os gebruik om die volgende aan te dui: "the purpose of an event or state, viewed in terms of its result", wat vertaal kan word as "purpose, intent, goal" (Louw \& Nida, 1996:

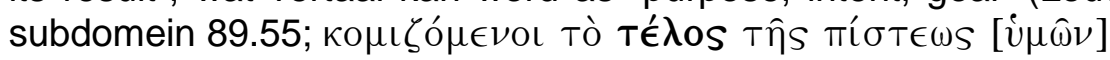

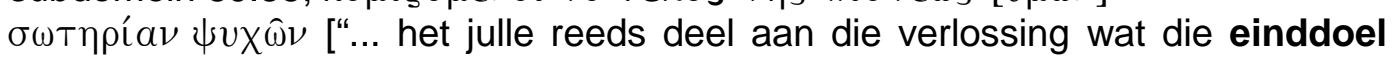
van julle geloof is". 1983-vertaling.]) Vergelyk ook Martin (1992:311-312) wat die frase vertaal as: "as you receive the end of your faith to be the salvation of your lives".

27 Louw en Nida (1996: subdomein 67.66) gee die volgende definisie van hierdie betekenis van Té $\lambda$ os "a point of time marking the end of a duration - 'end". Subdomein 67.78 is deel van subdomeine 67.65-67.72, gemerk deur Louw en Nida as "[a] point of time with reference to duration of time: beginning, end". 
$4: 7$

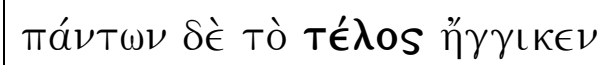

$4: 7$

Die einde van alles is naby

"Die einde van alles" is die tyd wanneer diegene wat die geadresseerdes beswadder ( $\beta \lambda \alpha \sigma \phi \eta \mu о \hat{\nu} \tau \epsilon S, 4: 4)$, "rekenskap moet gee aan Hom wat klaar staan om oor die lewendes en die dooies te oordeel" (4:5). Hieruit kan afgelei word dat "die einde van alles" is wanneer Christus terugkeer.

In 4:17 word Tó Té die evangelie van God wou luister nie") gebruik:

\begin{tabular}{|c|c|}
\hline $4: 17$ & $4: 17$ \\
\hline 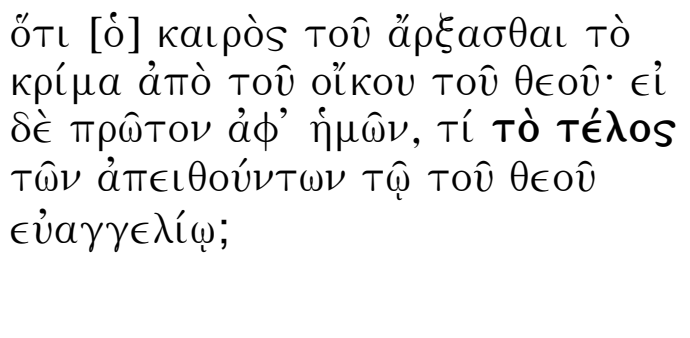 & $\begin{array}{l}\text { Die tyd vir die oordeel het aan- } \\
\text { gebreek; dit begin by die huis van } \\
\text { God. En as ook ons geoordeel word, } \\
\text { en dit is nog maar die begin, wat sal } \\
\text { die uiteinde dan wees van hulle wat } \\
\text { nie na die evangelie van God wou } \\
\text { luister nie? }\end{array}$ \\
\hline
\end{tabular}

Die genitief $\tau \hat{\omega} \nu \nu \dot{a} \pi \epsilon \iota \theta 0 v \dot{\nu} \tau \omega \nu$ is voorwerpsgenitief: dit gaan oor "die uiteinde" vir "hulle wat nie na die evangelie van God wou luister nie".

\section{- $\quad$ Gevolgtrekking}

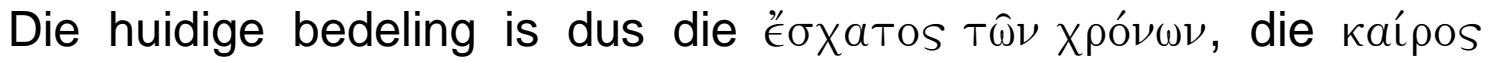
Éбxatos, die kaípos. Dit strek oor die era wat ingelei is deur die eerste koms van Christus, 28 en die ad quem word aangedui as die

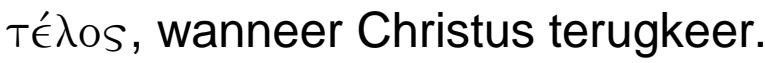

\subsection{2 'n Endlose volgende bedeling}

Die outeur se bewustheid van 'n finale toekomstige bedeling word betuig deur sy gebruik van die selfstandige naamwoord ó aíuv $(1: 25 ; 4: 11 ; 5: 11)$ en die etimologies-verwante byvoeglike naamwoord aíóvios (5:10).

28 In ooreenstemming met Beale (1997:14):

The New Testament repeatedly uses precisely the same phrase 'latter days' as found in the Old Testament prophecies. And the meaning of the phrase is identical, except for one difference: in the New Testament the end-days predicted by the Old Testament are seen as beginning their fulfilment with Christ's first coming.

Beale (1997:17-18) stel dit later meer eksplisiet: "Christ's life, and especially death and resurrection through the Spirit, launched the glorious end-time new creation of God". 
In 1:25 haal die outeur Jesaja 40:8 aan:

\begin{tabular}{|c|c|}
\hline $1: 25$ & $1: 25$ \\
\hline 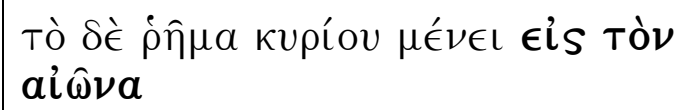 & $\begin{array}{l}\text { die woord van die Here, dit bly tot in } \\
\text { ewigheid }\end{array}$ \\
\hline
\end{tabular}

Die frase $\epsilon$ is Tòv aî̄ $\nu \alpha^{29}$ dui aan dat die woord van die Here tot in die komende bedeling stand hou, met geen einde wat vir daardie toekomstige bedeling aangedui word nie.

In 5:11 word dieselfde frase gebruik, maar hierdie keer in die meervoud ( $\epsilon$ is toùs aî̄vas), skynbaar sonder enige betekenisverskil van die enkelvoud in 1:25):

\begin{tabular}{|c|c|}
\hline $5: 11$ & $5: 11$ \\
\hline 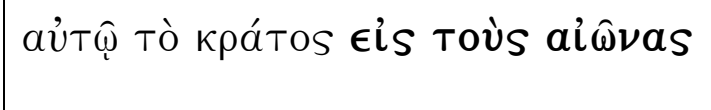 & $\begin{array}{l}\text { Aan Hom behoort die krag tot in } \\
\text { ewigheid }\end{array}$ \\
\hline
\end{tabular}

In 4:11 word 'n meer uitgebreide uitdrukking (Louw \& Nida, 1996:

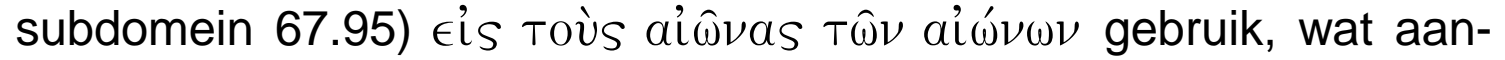
dui dat "die heerlikheid en krag" aan Jesus Christus behoort - selfs tot in die komende bedeling, wat blykbaar sonder einde is. Die frase gebruik die meervoud van ó alúv, en voeg die genitief van dieselfde woord by; sodoende word die betekenis in die finale lofprysing van die brief geïntensifiseer:

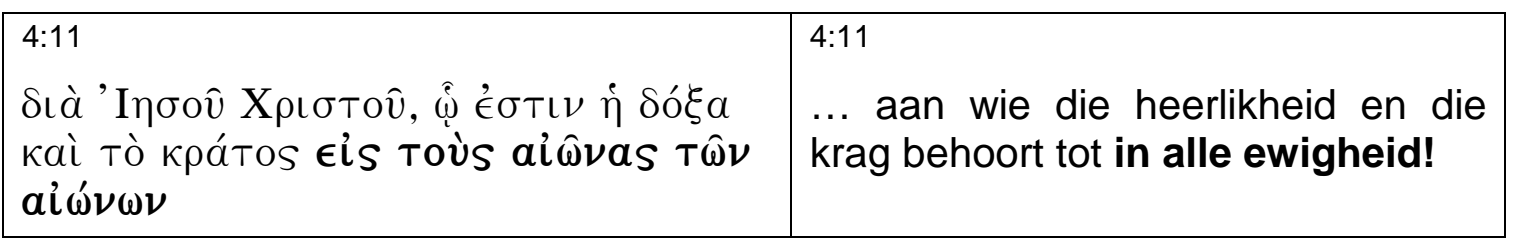

In 5:10 word die heerlikheid ( $\delta \xi^{\prime} \xi \alpha$ ) van God gekwalifiseer deur die byvoeglike naamwoord aívios, wat aandui dat die heerlikheid van God stand hou tot in die volgende bedeling:

29 Louw en Nida (1996: subdomein 67.95) gee die volgende definisie van hierdie betekenis van aíw $v$ : "unlimited duration of time, with particular focus upon the future", en gee die volgende moontlike Engelse vertaalekwivalente: "always, forever, forever and ever, eternally". Subdomein 67.95 is deel van sudomeine 67.78-67.117, gemerk deur Louw en Nida as "[d]uration of time without reference to points or units of time: time, spend time, always, eternal, old, immediately, young". 


\begin{tabular}{|c|c|}
\hline $5: 10$ & $5: 10$ \\
\hline 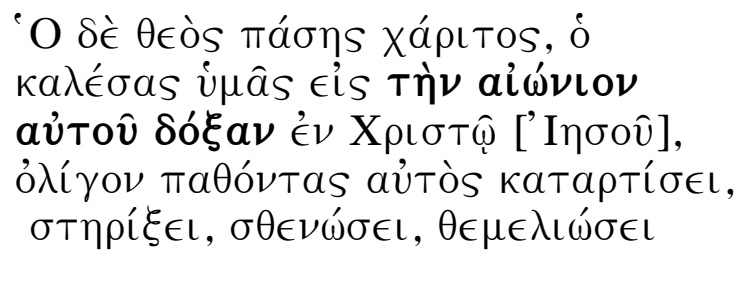 & $\begin{array}{l}\text { God wat alle genade gee en wat jul- } \\
\text { le geroep het om in Christus Jesus } \\
\text { deel te hê aan sy ewige heerlikheid, } \\
\text { sal julle, nadat julle 'n kort tydjie gely } \\
\text { het, self weer oprig en julle moedig, } \\
\text { sterk en standvastig maak. }\end{array}$ \\
\hline
\end{tabular}

\section{Gevolgtrekking}

Die outeur se gebruik van die selfstandige naamwoord ó aíuv (1:25; $4: 11 ; 5: 11)$ en die etimologies-verwante byvoeglike naamwoord aíúlos (5:10) lewer bewys van sy bewustheid van 'n toekomstige bedeling wat geen einde het nie.

\subsection{Verlossing as 'n huidige werklikheid, met volle vervulling in die toekoms}

Die outeur toon op verskillende wyses dat sy eskatologie verlossing as 'n huidige werklikheid met volle vervulling en/of openbaring in die toekoms, die volgende insluit:

- Die verskyning en/of openbaring ( $\phi a \nu \in \rho \omega \theta \in \hat{i} s / a ́ m o \kappa a ́ \lambda u \psi ı s)$ van verlossing/Jesus Christus/Christus se heerlikheid

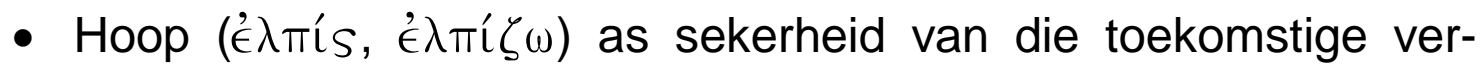
vulling van 'n huidige werklikheid

- Verlossing ( $\sigma \omega \tau \eta \rho i ́ \alpha)$ as huidige werklikheid, maar wat "voltooi" moet word

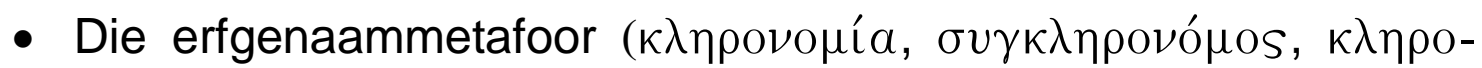
$\nu о \mu e^{\prime}(\omega)$

Hierdie vier kategorieë word voorts geïnterpreteer.

\subsubsection{Die verskyning en/of openbaring van verlossing/Jesus Christus/Christus se heerlikheid}

Die outeur maak dit duidelik dat daar 'n toekomstige openbaring ( $\phi \alpha \nu \in \rho \omega \theta \in \hat{\imath}$ lámoкá $\lambda v \psi \iota s)$ sal wees van die verlossing van die lesers, Jesus Christus, en Christus se heerlikheid.

In 1:5 word die verlossing van die geadresseerdes as 'n huidige werklikheid getipeer; die openbaarmaking daarvan lê egter in die toekoms ("reeds gereed om geopenbaar te word"): 


\begin{tabular}{|c|c|}
\hline 1:5 & $1: 5$ \\
\hline 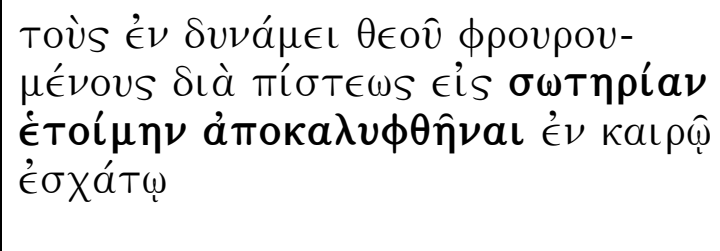 & $\begin{array}{l}\text { En deurdat julle glo, word ook julle } \\
\text { deur die krag van God veilig bewaar } \\
\text { vir die verlossing wat reeds } \\
\text { gereed is om in die laaste tyd } \\
\text { geopenbaar te word. }\end{array}$ \\
\hline
\end{tabular}

Die outeur noem 'n tyd wanneer Christus geopenbaar sal word

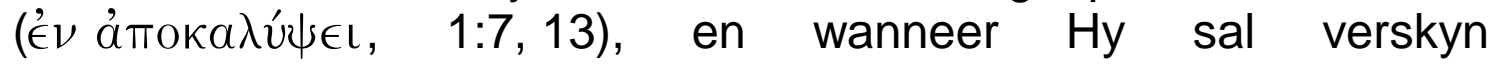

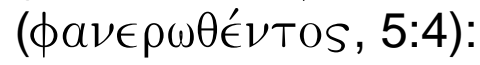

\begin{tabular}{l|l}
\hline $1: 7$ & $1: 7$
\end{tabular}

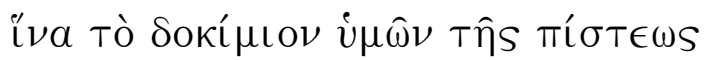

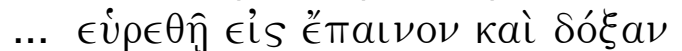

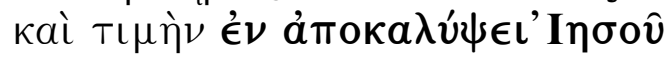
Xрıбтой sodat die egtheid van julle geloof getoets kan word ... sodat dit lof en heerlikheid en eer waardig mag wees by die openbaarmaking van Jesus Christus.
$1: 13$

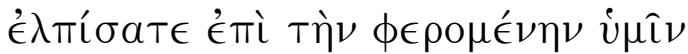

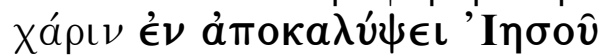
Xрıбтои
$1: 13$

en vestig julle hoop volkome op die genade wat julle deel sal word by die openbaarmaking van Jesus Christus.
$5: 4$

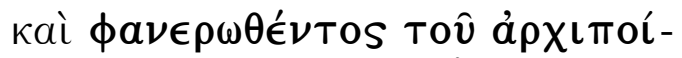

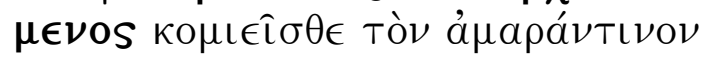

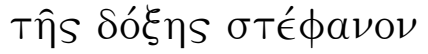

$5: 4$

En dan, wanneer die Opperherder verskyn, sal julle die heerlikheid as onverganklike kroon ontvang.

In die voorafgaande drie Skrifdele is die openbaarmaking van Christus toekomstig. Volgens 1:20 het Christus alreeds verskyn/is

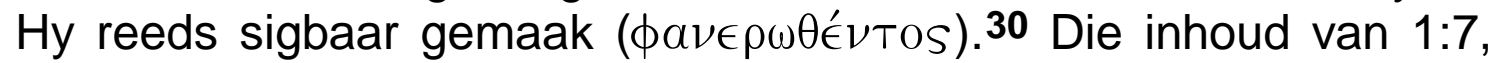
13 en 5:4 wys dus dat 'n "tweede" openbaarmaking sal plaasvind.

In 4:13 en 5:1 word dit gestel dat hierdie "tweede openbaarmaking" die tyd is waarop Christus se heerlikheid openbaar sal word:

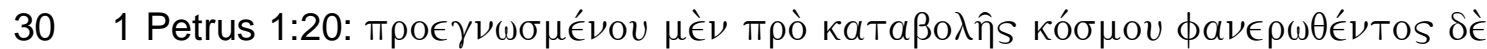

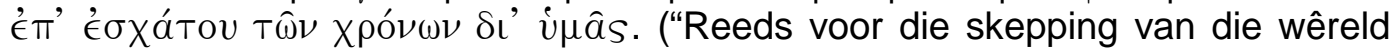
is Hy hiervoor bestem, maar ter wille van julle het Hy eers in hierdie eindtyd verskyn".) 


\begin{tabular}{|c|c|}
\hline $4: 13$ & $4: 13$ \\
\hline 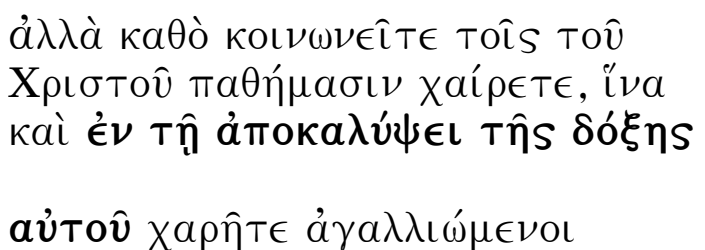 & $\begin{array}{l}\text { Wees liewer bly hoe meer julle in } \\
\text { die lyding van Christus deel, want } \\
\text { dan sal julle ook oorloop van } \\
\text { vreugde wanneer sy heerlikheid } \\
\text { openbaar gemaak word. }\end{array}$ \\
\hline
\end{tabular}

\begin{tabular}{|c|c|}
\hline 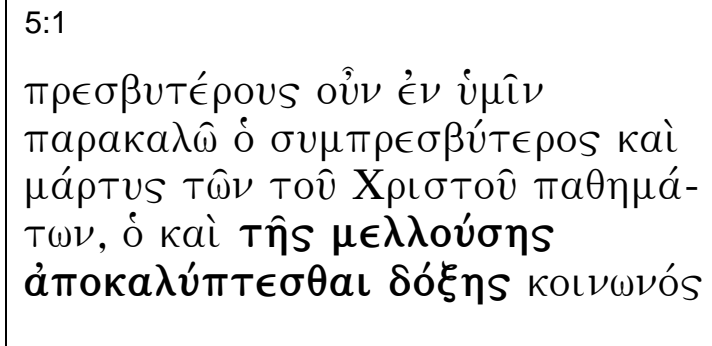 & $\begin{array}{l}\text { As mede-ouderling en getuie van } \\
\text { die lyding van Christus en ook } \\
\text { deelgenoot aan die heerlikheid } \\
\text { wat geopenbaar sal word, dring } \\
\text { ek by die ouderlinge onder julle } \\
\text { daarop aan. }\end{array}$ \\
\hline
\end{tabular}

Dit impliseer dat die heerlikheid van Christus 'n huidige werklikheid is; dit is egter tans "bedek". Dit moet "ontbloot" word, geopenbaar word. Die gelowiges ervaar nou reeds die werklikheid van Christus se heerlikheid ( $o$... $\delta o ́ \xi \eta s ~ \kappa o \iota \nu \omega \nu o ́ s)$, alhoewel hierdie heerlikheid eers in die toekoms geopenbaar sal word (5:1). Dit is eers dan wat

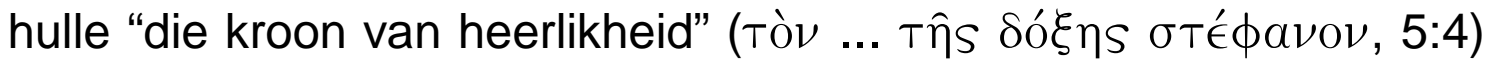
ontvang. Al hierdie dinge sal maak dat die geadresseerdes bly is en uitroep van vreugde (4:13) wanneer Christus se heerlikheid geopenbaar word. 31

Hierdie "reeds en nog nie"32-karakter van die heerlikheid van Christus is ook waar van die geloof van die geadresseerdes en die genade wat hulle ontvang: Die "opregtheid van julle geloof"

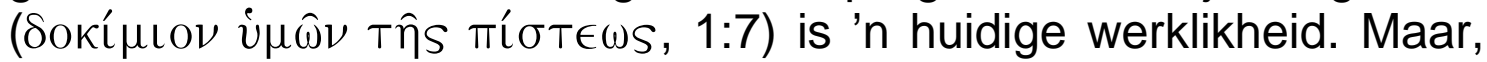
die feit dat "opregtheid van julle geloof" op lofprysing, roem en eer uitloop, sal eers duidelik word ( $\epsilon \dot{v} \rho \in \theta \hat{n}, 1: 7)$ op 'n toekomstige tydstip, naamlik wanneer Jesus Christus geopenbaar word. Op hierdie tydstip sal die genade ook gebring word (

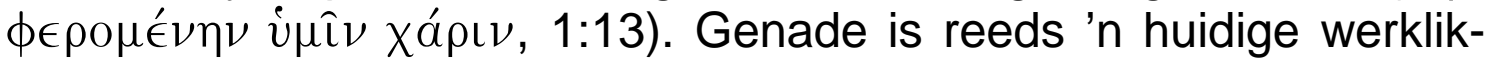

31 Só ook Elliott (1996:275): "1 Peter regards the suffering of God's people as a sign of the end time, the day of judgment and salvation (1:6-9; 4:5-7, 17-19)". Hierdie is teenoor Parker (1994:30), wat die openbaring van Christus se heerlikheid sien as iets wat gebeur wanneer die Christene swaarkry. Hy vertaal die frase as: "so that you may be glad and shout for joy in the revelation of his glory".

32 Beale (1997) het redelik onlangs die "reeds en nog nie" eskatologiese sentrum, wat voorheen deur Geerhardus Vos (1979), Oscar Cullman (1964), Herman Ridderbos (1975), en George Eldon Ladd (1974) geponeer is, verder verfyn. Beale (1997:21) beskou die "nuwe skepping" as die kernverwoording van eskatologie. 


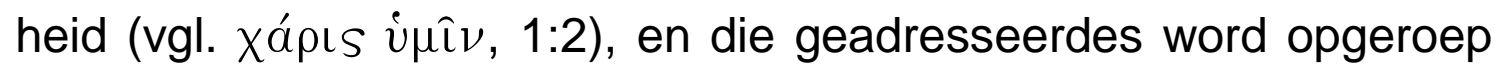
om hulle hoop op die "volle openbaarmaking" van hierdie genade te stel.

\subsubsection{Hoop ('́̇तís): 'n sekerheid van die toekomstige vervulling van verlossing as 'n huidige werklikheid}

Nog 'n woord wat die eskatologie van 1 Petrus aanmerk, is

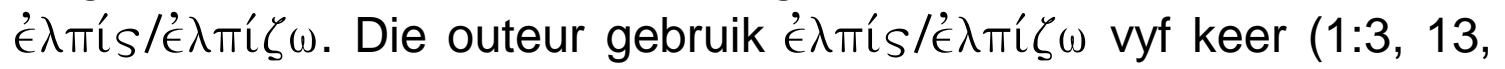
$21 ; 3: 5,15)$ :

\begin{tabular}{|c|c|}
\hline $1: 3$ & $1: 3$ \\
\hline 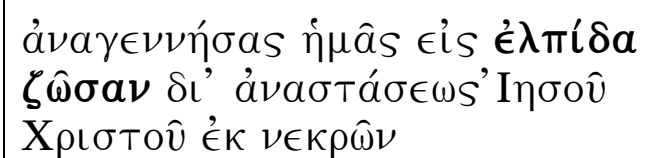 & $\begin{array}{l}\text { Hy het ons nuut verwek tot 'n lewende } \\
\text { hoop deur die opstanding van Jesus } \\
\text { Christus uit die dood. }\end{array}$ \\
\hline
\end{tabular}

\begin{tabular}{|c|c|}
\hline $3: 15$ & $3: 15$ \\
\hline 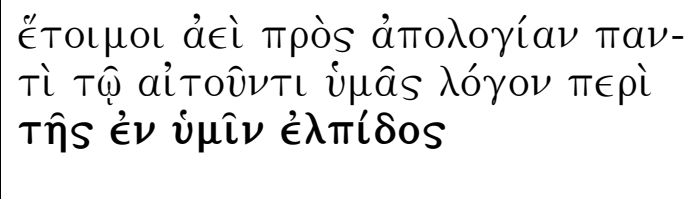 & $\begin{array}{l}\text { Wees altyd gereed om 'n antwoord te } \\
\text { gee aan elkeen wat van julle 'n } \\
\text { verduideliking eis oor die hoop wat in } \\
\text { julle is. }\end{array}$ \\
\hline
\end{tabular}

\begin{tabular}{|c|c|}
\hline 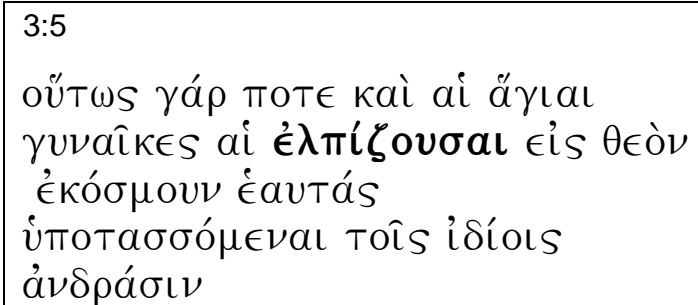 & $\begin{array}{l}\text { 3:5 } \\
\text { In die ou dae het die gelowige vrouens } \\
\text { wat op God gehoop het, hulle ook so } \\
\text { versier: hulle was aan hulle mans } \\
\text { onderdanig. }\end{array}$ \\
\hline
\end{tabular}

\begin{tabular}{|c|c|}
\hline 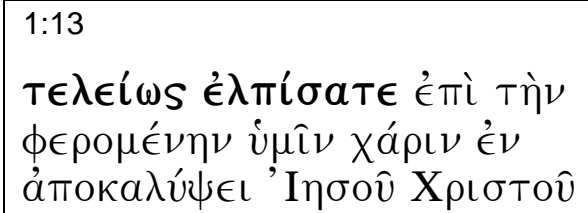 & $\begin{array}{l}\text { 1:13 } \\
\text { en vestig julle hoop volkome op die } \\
\text { genade wat julle deel sal word by die } \\
\text { openbaarmaking van Jesus Christus. }\end{array}$ \\
\hline
\end{tabular}

\begin{tabular}{|c|c|}
\hline $1: 21$ & $1: 21$ \\
\hline 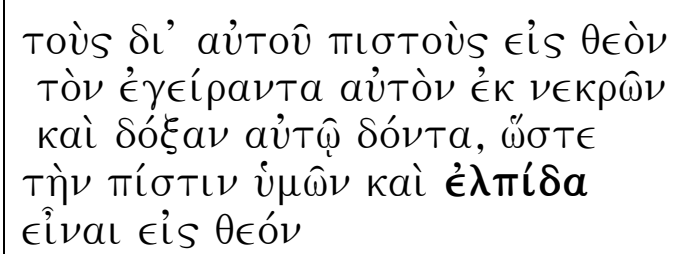 & $\begin{array}{l}\text { Deur Hom glo julle in God wat Hom uit } \\
\text { die dood opgewek en aan Hom } \\
\text { heerlikheid gegee het. Daarom is julle } \\
\text { geloof en hoop op God gerig. }\end{array}$ \\
\hline
\end{tabular}

In twee van hierdie voorkomste word die "hoop" ('́ $\lambda \pi$ mís) deur 'n byvoeglike naamwoord gekwalifiseer: in 1:3 met "lewe" 


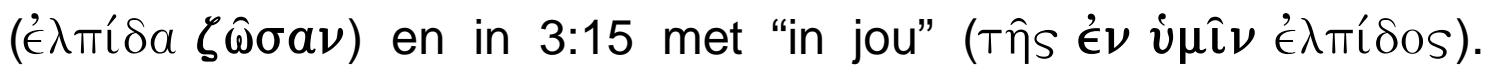
Albei hierdie kwalifikasies beklemtoon die feit dat die hoop 'n huidige werklikheid is. 33 In 1:3 word die hoop ook gekwalifiseer met "deur die opstanding van Jesus Christus uit die dood"

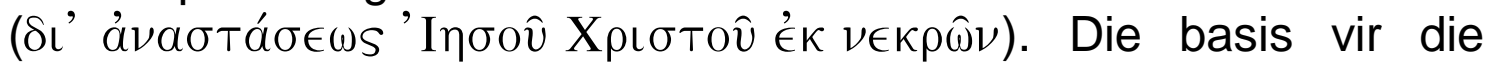
hoop is dus die opstanding van Jesus, 'n gebeure wat in die verlede plaasgevind het.

In 1:21 en 3:5 is die voorwerp van die hoop $\epsilon i s \quad \theta \in o ́ \nu$, en in 1:13 is

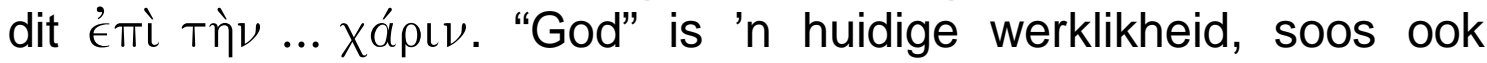
"genade".

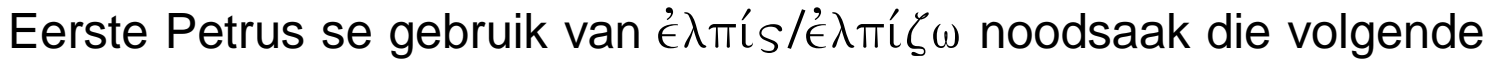
definisie van "hoop": "om uit te sien na die vervulling van God se verlossingsbeloftes met selfvertroue, gebaseer op die opstanding van Christus". 34,35

\title{
5.2.3 Verlossing ( $\sigma \omega \tau \eta \rho i ́ a)$ as huidige werklikheid, maar wat nog "voltool" moet word
}

Die hele idee van die "reeds en nog nie" is hierbo aangeraak met

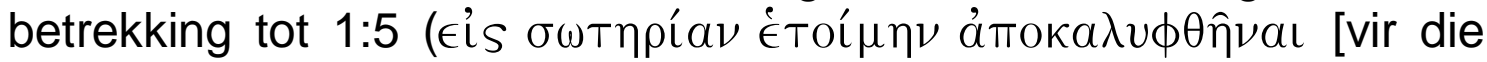
verlossing wat reeds gereed is om geopenbaar te word]) en 1:9

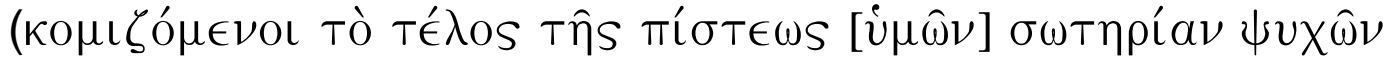

33 Miller (1995:138) stem saam:

\begin{abstract}
A living hope focuses on a future that has already happened, but is incomplete; something not solely yet to be, but something which is already in existence. ... It is a confidence in the future born of an event in the past.
\end{abstract}

34 Cullmann (1964:87) beskryf Jesus se eerste koms paslik as "D-day", en die tweede koms as "V-day", en voeg dan by: "The hope of the final victory is so much more vivid because of the unshakeably firm conviction that the battle that decides the victory has already taken place".

35 Hierdie definisie verskil in sommige aspekte van die definisie van Louw en Nida (1996). Hulle leksikon dui twee betekenisse aan vir $\epsilon^{\prime} \lambda \pi i ́ \zeta \omega$ "hope for" ("to look forward with confidence to that which is good and beneficial - 'to hope, to hope for, hope"', subdomein 25.59) en "expect" ("to expect, with the implication of some benefit - 'to expect, to hope"', subdomein 30.54).

'E $\lambda$ mís het drie verwante betekenisse, almal van hulle in die groep van subdomeine wat Louw en Nida tipeer as "to expect, with the implication of some benefit - 'to expect, to hope"' (subdomeine 25.59-25.64). Die drie verwante betekenisse is: "hope" ("to look forward with confidence to that which is good and beneficial - 'to hope, to hope for, hope'", subdomein 25.59); "what is hoped for" ("that which is hoped for - 'what is hoped for, hope," subdomein 25.61); en "basis for hope" ("that which constitutes the cause or reason for hoping - "the basis for hope, the reason for hope"', subdomein 25.62). 
[julle het reeds deel aan die verlossing wat die einddoel van julle geloof is]). By hierdie verklaring is dit nodig om nou ook

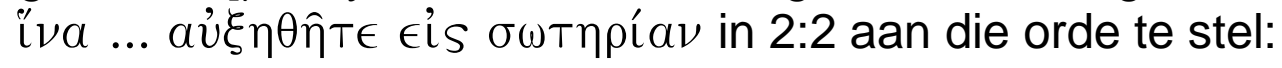

\begin{tabular}{|c|c|}
\hline $2: 2$ & $2: 2$ \\
\hline 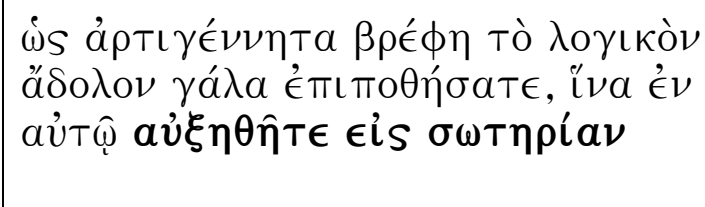 & $\begin{array}{l}\text { Soos pasgebore kindertjies smag na } \\
\text { melk, moet julle smag na die suiwer } \\
\text { geestelike melk, sodat julle daardeur } \\
\text { kan opgroei in julle verlossing. }\end{array}$ \\
\hline
\end{tabular}

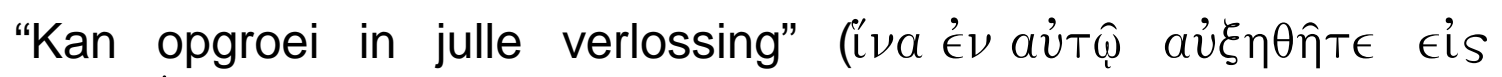
$\sigma \omega \tau \eta \rho i ́ \alpha \nu$ ) beteken nie dat die geadresseerdes weens die melk groei en as 'n resultaat van die groei verlossing ontvang nie. ${ }^{36}$ Dit beteken eerder dat die melk hulle in staat sal stel om op te leef na hulle status as kinders van God. Sedert hulle nuutverwekking en weergeboorte is hulle reeds gered en daarom kinders van God. Hulle het nou die plig om soos verloste persone te leef as kinders van God. Hoe meer hulle die suiwer melk van God se woord inneem en verteer, hoe meer sal hulle leefstyl die toonbeeld wees van hulle status as persone wat (nuut) deur God verwek is as kinders van God. Die "ophou met elke vorm van kwaad ..." (1 Pet. 2:1) is 'n voorbeeld van hierdie einste leefstyl.

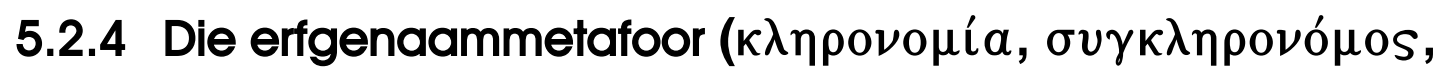 $\kappa \lambda \eta \rho о \nu o \mu \epsilon ́(\omega)$}

Die erfgenaammetafoor, wat ' $n$ voortsetting is van die vader/ opwekkingmetafoor van 1:3, maak 'n groot bydrae tot die eskatologie van 1 Petrus. Die outeur van 1 Petrus gebruik die erfgenaammetafoor drie keer: $1: 4 \quad$ ( $\epsilon$ is $\kappa \lambda \eta \rho о \nu о \mu i ́ \alpha \nu), \quad 3: 7$

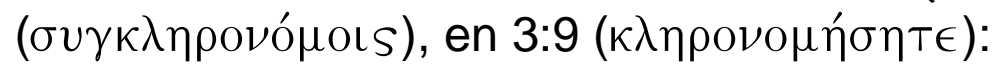

36 Hierdie staan teenoor Achtemeier (1996:147) en Michaels (1988:89). Achtemeier

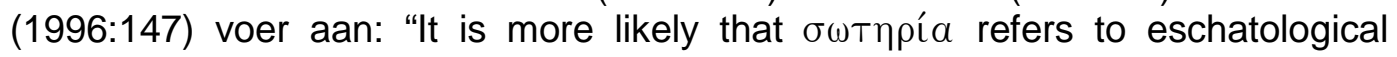
deliverance than to Christian maturity". Dit hou in dat die groei voorwaardelik is vir 'n persoon se verlossing ten tye van die finale goddelike oordeel - 'n motief wat nie by die makro-argument van die brief inpas nie (wat juis die voltooide status van die geadresseerdes se verlossing beklemtoon). Michaels (1988:89) se standpunt is dieselfde as dié van Achtemeier: " $\epsilon \dot{i} S \sigma \omega T \eta \rho i ́ a \nu$ in our passage points to a vindication arising inevitably, almost 'naturally', out of the spiritual growth that results from receiving 'pure spiritual milk"'. 
\begin{tabular}{|l|l|}
\hline $1: 4$ & $1: 4$
\end{tabular}

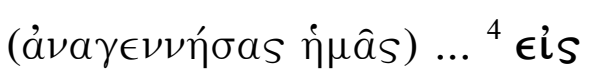

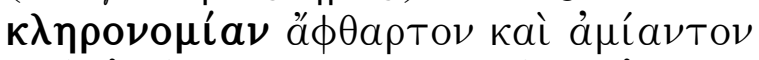

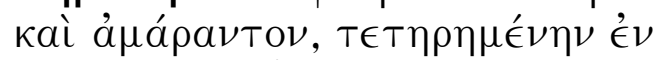
oúpavô̂s Eis ưrâs

(Hy het ons nuut-verwek) tot 'n onverganklike, onbesmette en onverwelklike erfenis wat in die hemel vir julle in bewaring gehou word.

\section{3:7

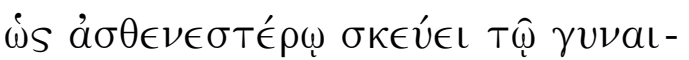 кеا́

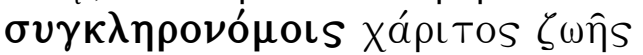

$3: 7$

Bewys eer aan hulle as die swakker geslag wat julle mede-erfgename is van die lewe as genadegawe.

\section{3:9

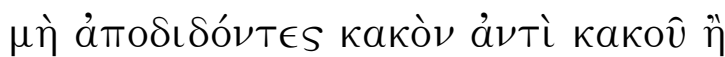

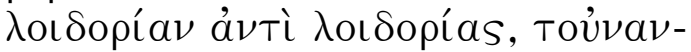

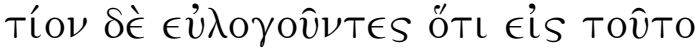

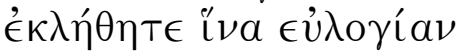

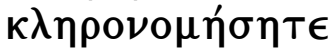

$3: 9$

Moenie kwaad met kwaad vergeld of belediging met belediging nie. Inteendeel, antwoord met 'n seënwens, want daartoe is julle geroep, sodat julle seën kan beërf.

Die erfgenaambeeld is seker die mees ondubbelsinnige aanduiding dat die eskatologie van 1 Petrus 'n huidige werklikheid inhou, in afwagting van volle vervulling in die toekoms. ' $n$ Persoon wat 'n erfgenaam is, het hierdie status in die hede. 37 Die erfporsie self lê egter in die toekoms, en die erfgenaam kan die absolute sekerheid hê dat hy/sy hierdie erfporsie sal ontvang. ${ }^{38}$

37 Hammer (1996:416) stel tereg: “The event of Jesus' resurrection makes the hope of future resurrection a present reality and becomes the basis for the future imperishable inheritance".

38 Dit verskil in sommige aspekte van die definisie wat Louw en Nida (1996) gee, veral aangesien hulle definisie nie die metaforiese gebruik van die woorde verreken nie. Die leksikon dui twee betekenisse vir $\kappa \lambda \eta \rho о \nu о \mu \epsilon ́ \omega$ aan: "receive" ("to receive something of considerable value which has not been earned - "to receive, to be given, to gain possession of '", subdomein 57.131); en "inherit" ("to receive a possession or benefit as a gift from someone who has died, generally a parent - 'to inherit, to receive from a deceased parent"', subdomein 57.138).

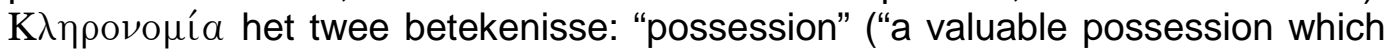
has been received - 'possession"', subdomein 57.132); en "inheritance" ("that which is received from a deceased person - 'inheritance'", subdomein 57.140).

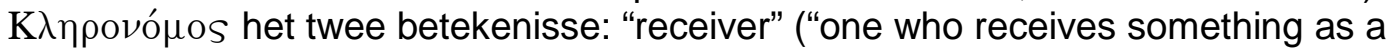
gift - 'one who receives, one who comes into possession of, receiver, heir"', subdomein 57.133); en "heir" ("the person who inherits possessions - 'heir"', subdomein 57.139). Al hierdie betekenisse val in die groep subdomeine wat Louw en Nida tipeer as "receive"; die betekenisse bevat 'n oordrag van voordele 


\subsection{God as regter, hede en toekoms}

Dit wat die outeur van 1 Petrus skryf oor die oordeel van God is nog 'n venster op sy eskatologie. Hy verwys na God se oordeel met die werkwoord $\kappa ́^{\prime} \nu \omega(1: 17,2: 23$, en 4:5) en die selfstandige

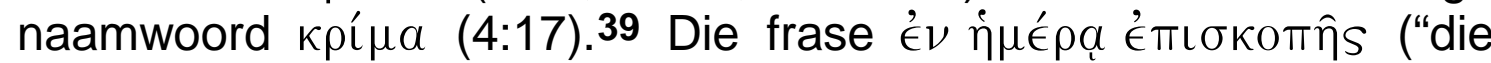
dag van besoeking", 2:12) verwys waarskynlik na die dag wanneer

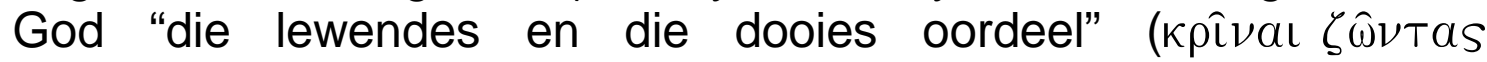
kaì $\nu \in \kappa \rho o u ́ s, ~ 4: 5) .40$ Hierdie ses voorkomste word vervolgens bestudeer.

Dit is opmerklik dat die subjek van die oordeel slegs in een van hierdie gevalle eksplisiet aangedui word, naamlik in 1:17:41

\begin{tabular}{|c|c|}
\hline 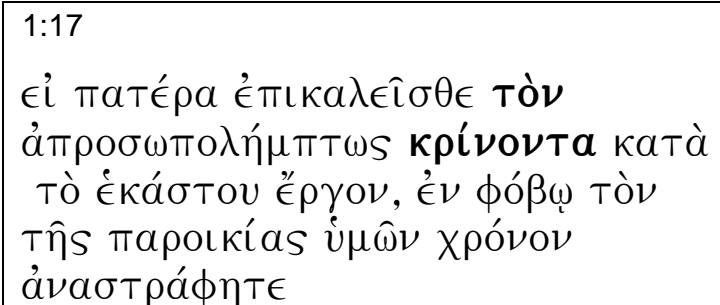 & $\begin{array}{l}\text { 1:17 } \\
\text { Aangesien julle Hom as Vader aan- } \\
\text { roep wat oor elke mens onpartydig } \\
\text { volgens sy dade oordeel, lewe dan in } \\
\text { eerbied vir Hom gedurende die tyd } \\
\text { van julle vreemdelingskap. }\end{array}$ \\
\hline
\end{tabular}

Die tyd wat God sal begin met die oordeel, word hier nie eksplisiet aangedui nie. In die lig van $4: 5$ is dit waarskynlik op die dag wanneer God "die lewendes en die dooies oordeel". Op sigself mag dit klink asof die outeur die komende oordeel van die Vader gebruik om sy lesers/hoorders af te skrik van 'n immorele lewe. Die verwysing na die komende oordeel van die Vader dien egter as ' $n$ positiewe motivering om nie die reg in eie hande te neem en die

op objekte waar die fokus op die aktiwiteit of die ervaring van die ontvanger val (subdomeine 57.125-57.141).

39 Louw en Nida (1996: subdomein 56.20) gee die volgende definisie vir hierdie betekenis van $\kappa \rho i ́ \omega \omega / \kappa \rho i ́ \mu \alpha$ : "to decide a question of legal right or wrong, and thus determine the innocence or guilt of the accused and assign appropriate punishment or retribution - 'to decide a legal question, to act as a judge, making a legal decision, to arrive at a verdict, to try a case'". Subdomein 56.20 is deel van subdomeine 56.20-56.34, deur Louw en Nida getipeer as "judge, condemn, acquit".

40 Vergelyk ook Louw en Nida (1996: subdomein 34.51). Hierdie leksikon gee die

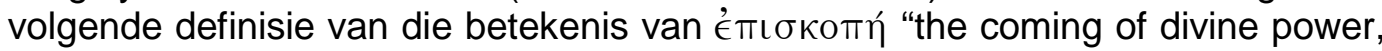
either for benefit or judgment - 'coming, visitation'". Subdomein 34.51 is deel van subdomeine 34.50-34.52, deur Louw en Nida getipeer as "visit". Parker (1994:30) verstaan egter die besoeking Christologies: "1 Peter uses this idea of the incarnation as visitation to describe Christ's presence". Na my mening laat Parker se interpretasie egter nie reg geskied aan die argument van die perikoop nie.

41 Die konteks maak dit egter duidelik dat God in elkeen van die vyf verskynings die subjek van die oordeel is. 
verontregting waaraan die lesers onderworpe was, te vergeld nie. Hulle moenie vir mense bang wees of hulle laat afskrik nie

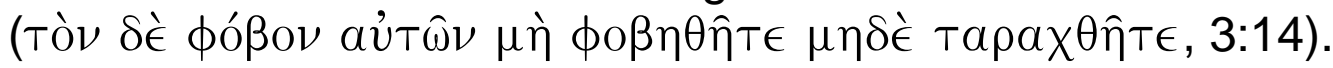

Hierdie positiewe gebruik van die komende oordeel van God blyk ondubbelsinnig uit 2:12:

\begin{tabular}{|c|c|}
\hline $2: 12$ & 2:12 \\
\hline 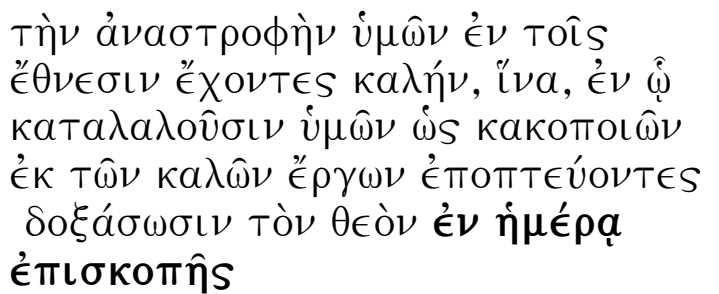 & $\begin{array}{l}\text { Gedra julle altyd goed onder die } \\
\text { heidene sodat, al praat hulle kwaad } \\
\text { van julle asof julle misdadigers is, } \\
\text { hulle julle voorbeeldige lewe kan sien } \\
\text { en God kan verheerlik op die dag } \\
\text { van besoeking. }\end{array}$ \\
\hline
\end{tabular}

Die lesers/hoorders word op 'n positiewe wyse gemotiveer om nie te vergeld nie: dié wat tans van hulle kwaadpraat asof hulle misdadigers is, sal hulle houding algeheel verander wanneer God op die oordeelsdag regspreek.

In 4:5 word hierdie positiewe gebruik van die komende oordeel van God nog duideliker:

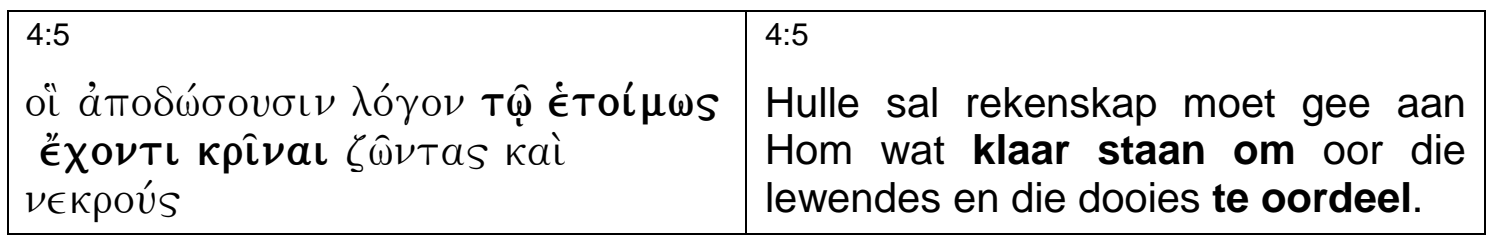

In die voorafgaande verse (4:3-4) noem die outeur die beswaddering ( $\beta \lambda \alpha \sigma \phi \eta \mu o v \nu \tau T \epsilon S, 4: 4)$ van die heidene wat die lesers/hoorders moes verduur, en in 4:5 vertroos hy die lesers deur te noem dat hierdie einste persone sal moet rekenskap gee aan "Hom wat klaar staan om ... te oordeel". Die stelling in 4:7 sluit die argument van hierdie perikoop af: "Die einde van alles is naby"

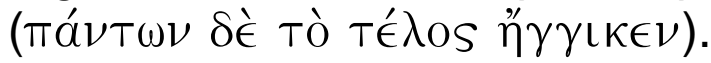

Die tema word egter in die volgende perikoop (4:12-19) hervat, ná 4:7b-11. Die lesers/hoorders word opgeroep om nie "verbaas (te) wees oor die vuurproef waaraan julle onderwerp word nie. Dit is nie iets vreemds wat met julle gebeur nie" (4:12). Die outeur motiveer sy geadresseerdes, op 'n positiewe wyse, om aan te hou goed doen deur hulle in 4:17 te herinner aan die verskriklike ervaring wat wag vir diegene wat hulle teister wanneer God kom oordeel: 


\begin{tabular}{|c|c|}
\hline $4: 17$ & $4: 17$ \\
\hline 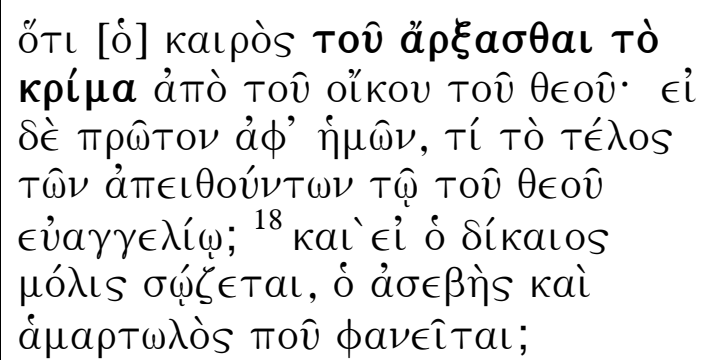 & $\begin{array}{l}\text { Die tyd vir die oordeel het } \\
\text { aangebreek; dit begin by die huis } \\
\text { van God. En as ook ons geoordeel } \\
\text { word, en dit is nog maar die begin, } \\
\text { wat sal die uiteinde dan wees van } \\
\text { hulle wat nie na die evangelie van } \\
\text { God wou luister nie? }\end{array}$ \\
\hline
\end{tabular}

Die boodskap is duidelik: die lesers/hoorders moenie vergeld wanneer hulle gebuk gaan onder allerlei soorte diskriminasie en verstoting deur nie-Christene nie. Hulle moet in die voetspore van Jesus volg en die saak toevertrou aan "aan Hom wat regverdig oordeel" (2:23):42

\begin{tabular}{|c|c|}
\hline $2: 23$ & $2: 23$ \\
\hline 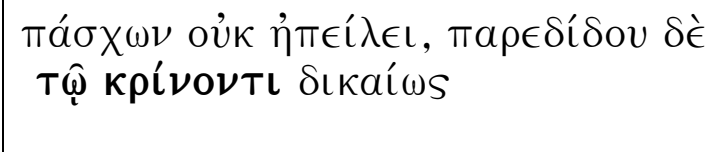 & $\begin{array}{l}\text { Toe Hy gely het, het Hy nie gedreig } \\
\text { nie, maar alles oorgelaat aan Hom } \\
\text { wat regverdig oordeel. }\end{array}$ \\
\hline
\end{tabular}

In hierdie analise van die oordeel deur God het twee sake duidelik geword:43

- Die oordeel van God vind in die toekoms plaas, "op die dag van afrekening" (2:12). In die hede is Hy egter die een wat "klaar staan om ... te oordeel" (4:5), en die "tyd vir die oordeel het aangebreek; dit begin by die huis van God" (4:17).

- Die outeur gebruik hierdie komende oordeel van God nie as 'n negatiewe afskrikmiddel vir die geadresseerdes nie, maar as 'n positiewe motivering - op die dag van afrekening sal hulle gevindiseer word, en hulle verontregters sal ly onder die nega-

Só ook Elliott (1996:272):

The socially estranged yet divinely elected company of believers was portrayed as the eschatological fulfilment of the covenant people of God. Suffering Christians were provided a rationale for endurance, hope, and God-pleasing conduct through their solidarity with the rejected yet divinely vindicated Lord.

43 Dalton (1968:7) waarsku tereg daarteen om eenvoudig en sonder voorbehoud menslike en regswette op God toe te pas.

God can never be a judge like a human judge. There is no law above him defining his sphere of action: he is the law. And, in any case, God is primarily a God who loves, a God who saves. Hence any eschatological statement set in the context of future judgment must take into account the inadequacy of this context and must allow for this inadequacy if conclusions unworthy of God are to be avoided. 
tiewe oordeel wat hulle verdien. Die beteken dat die geadresseerdes nog meer rede het om "hulle lewe toe te vertrou aan die getroue Skepper, en aan te hou goed doen"

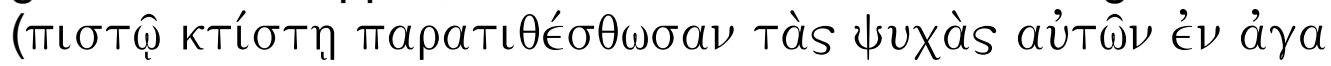
Өотоцї) (4:19).

\section{Gevolgtrekking: hoop en vindikasie vir tydelike en permanente uitlanders}

Die outeur van 1 Petrus vooronderstel twee bedelings: 'n huidige bedeling wat strek vanaf die eerste koms van Christus, en wat as ad quem het die terugkeer van Christus; en 'n toekomstige bedeling wat blykbaar nie 'n einde het nie (vgl. 5.1 hierbo).

Die eskatologie van 1 Petrus word beheers deur die beeld in 1:3 van die pa wat verwek, die stelling dat die Vader die geadresseerdes

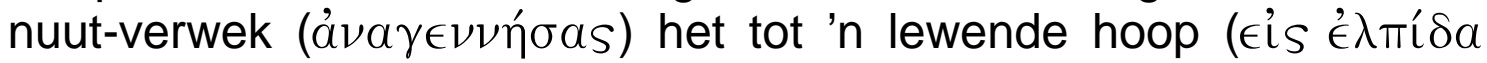
$\zeta(\hat{\omega} \sigma \alpha \nu)$ deur die opstanding ( $\delta \iota^{\prime}$ à $\left.\nu \alpha \sigma \tau a ́ \sigma \epsilon \omega s\right)$ van Jesus Christus uit die dood (1:3). Hierdie beeld vorm die basis vir die "reeds en nog nie"-eskatologie. Die status van die geadresseerdes as verlostes is 'n huidige werklikheid (die "reeds"-element); dit moet egter nog tot volle vervulling kom (die "nog nie"-element).

Die mees ondubbelsinnige aanduiding dat die eskatologie van 1 Petrus ' $n$ huidige werklikheid is wat wag op toekomstige vervulling, is die erfgenaambeeld (vgl. 5.2.4 hierbo) wat 'n voortsetting is van die pabeeld. ' $n$ Persoon wat 'n erfgenaam is, het hierdie status reeds in die hede. Die ontvangs van die erfporsie lê egter iewers in die toekoms. Die erfgenaam kan egter absolute sekerheid hê dat hy/sy hierdie erfporsie sal ontvang.

Die lesers het die plig om op te leef na hulle status as verlostes, hulle status as kinders van God. Hoe meer hulle die suiwer melk van God se woord inneem en verteer, hoe meer sal hulle leefstyl die toonbeeld wees van hulle status as persone wat deur die Vader nuutverwek is (2:1-3) (vgl. 5.2.3 hierbo).

Die "nog nie" van die eskatologie word duidelik uit die feit dat 'n openbaarmaking nog nodig is (vgl. 5.2.1 hierbo). Die heerlikheid van Christus ís 'n huidige werklikheid, maar "verborge" - en dit moet nog openbaar gemaak word (5:1). Wanneer hierdie openbaarmaking plaasvind, sal hulle "die heerlikheid as onverganklike kroon ontvang" (5:4), en sal hulle bly wees en uitroep van vreugde (4:13). Die egtheid van hulle geloof sal eers blyk (1:7) wanneer Jesus Christus terugkeer. Op hierdie tydstip sal genade hulle deel word (1:13). 
Nog 'n "nog nie"-element van die eskatologie van 1 Petrus word duidelik uit wat oor die toekomstige oordeel van God geskryf is, "op die dag van besoeking" (2:12) (vgl. 5.3 hierbo). In die hede is God die een wat "klaar staan om ... te oordeel" (4:5), en die "tyd vir die oordeel het aangebreek; dit begin by die huis van God" (4:17). Hierdie komende oordeel van God dien as 'n positiewe motivering vir die geadresseerdes om in goeie dade te volhard en om nie te vergeld nie: op die dag van besoeking sal hulle gevindiseer word en hulle verontregters sal ly onder die negatiewe oordeel wat hulle verdien. Die geadresseerdes het daarom soveel te meer rede om die voorbeeld van Christus te volg van Wie gesê word: "Toe Hy beledig is, het Hy nie terug beledig nie, toe Hy gely het, het Hy nie gedreig nie, maar alles oorgelaat aan Hom wat regverdig oordeel" $(2: 23)$. Só moet hulle ook "hulle lewe toevertrou aan die getroue Skepper, en aanhou goed doen" (4:19).

Die eskatologie van 1 Petrus hou dus in dat die geadresseerdes deur God nuut-verwek is tot 'n lewende hoop. Hierdie lewende hoop stel hulle in staat om met vertroue op die vervulling van God se beloftes te wag, 'n vertroue gebaseer op die opstanding van Christus (1:3). Op hierdie manier is die "tydelike en permanente uitlanders" bemagtig om op hulle moeilike omstandighede te reageer deur nie te vergeld nie, maar deur aan te hou goed doen, aangesien hulle weet dat hulle deur God se oordeel, wanneer Christus terugkeer, gevindiseer sal word. Die eskatologie van 1 Petrus verskaf dus hoop en vindikasie vir gelowiges wat onder diskriminasie en verontregting gebuk gaan omdat hulle tydelike en permanente uitlanders is.

Hierdie eskatologie het 'n kragtige boodskap selfs vir vandag. Dit bemagtig Christene om eties in die huidige bedeling te volhard met die "reeds en nog nie"-status van hulle verlossing.

\section{Geraadpleegde bronne}

ACHTEMEIER, P.J. 1996. 1 Peter: a commentary on first Peter. Minneapolis: Fortress.

AUNE, D.E. 1996. Early Christian eschatology. (In Freedman, D.N., ed. The Anchor Bible Dictionary. Vol. 2. New York: Doubleday. p. 594-608.)

BALCH, D.L. 1981. Let wives be submissive: the domestic code in 1 Peter. Chicago: Scholars Press.

BEALE, G.K. 1997. The eschatological conception of New Testament theology. (In Brower, K.E. \& Elliott, M.W., eds. Eschatology in Bible \& theology: evangelical essays at the dawn of a new millennium. Downers Grove: InterVarsity. p. 11-52.)

BEARE, F.W. 1970. The first epistle of Peter. 3rd ed. Oxford: Blackwell.

CULLMANN, O. 1964. Christ and time. Philadelphia: Westminster. 
DALTON, W.J. 1968. Aspects of New Testament eschatology. Nedlands: University of Western Australia Press. (Lectures in Biblical Studies, 4.)

DENNISTON, J.D. 1966. The Greek particles. Oxford: Clarendon.

ELLIOTT, J.H. 1976. The rehabilitation of an exegetical step-child: 1 Peter in recent research. Journal of Biblical literature, 95(2):243-254.

ELLIOTT, J.H. 1981. A home for the homeless: a sociological exegesis of 1 Peter, its situation and strategy. Philadelphia: Fortress.

ELLIOTT, J.H. 1986. 1 Peter, its situation and strategy: a discussion with David Balch. (In Talbert, C.H., ed. Perspectives on first Peter. Macon: Mercer University Press. p. 61-78.)

ELLIOTT, J.H. 1996. Peter, first epistle of. (In Freedman, D.N. The Anchor Bible Dictionary. Vol. 5. New York: Doubleday. p. 269-278.)

FELDMEIER, R. 1992. Die Christen als Fremde: die Metapher der Fremde in der antiken Welt, im Urchristentum und im 1. Petrusbrief. Tübingen: Mohr.

GARRETT, S.R. 1992. Sociology of early Christianity. (In Freedman, D.N. The Anchor Bible Dictionary. Vol. 6. New York: Doubleday. p. 89-99.)

GOPPELT, L. 1978. Der erste Peterbrief. 8. Ausg. Göttingen: Vandenhoeck \& Ruprecht.

HAMMER, P.L. 1996. Inheritance (NT). (In Freedman, D.N. The Anchor Bible Dictionary. New York: Doubleday. 3:415-416.)

LADD, G.E. 1974. Presence of the future. Grand Rapids: Eerdmans.

LOUW, J.P. \& NIDA, E.A. 1988. Greek-English Lexicon of the New Testament. 2 vols. New York: United Bible Societies.

LOUW, J.P. \& NIDA, E.A. 1996. Greek-English Lexicon of the New Testament: based on semantic domains. 2nd ed. Electronic reproduction. New York: United Bible Societies.

MARTIN, T. 1992. The present indicative in the eschatological statements of 1 Peter 1:6, 8. Journal of Biblical literature, 111(2):307-312.

MICHAELS, J. Ramsey. 1988. 1 Peter. Waco: Word Books.

MILLER, D.G. 1995. The resurrection as the source of living hope: an exposition of 1 Peter 1:3. Horizons in Biblical theology, 17(2):132-140.

MOULE, C.F.D. 1956-1957. The nature and purpose of first Peter. New Testament studies, 3:1-11.

PARKER, D.C. 1994. The eschatology of 1 Peter. Biblical theology bulletin, 24(1):27-32.

RICHARD, E. 1986. The functional Christology of first Peter. (In Talbert, C.H., ed. Perspectives on first Peter. Macon: Mercer University Press. p. 121139.)

RIDDERBOS, H. 1975. Paul: an outline of his theology. Grand Rapids: Eerdmans.

SELAND, T. 2005. Strangers in the light: philonic perspectives on Christian identity in 1 Peter. Leiden: Brill.

THOMAS, G.J. 1997. A holy God among a holy people in a holy place: the enduring eschatological hope. (In Brower, K.E. \& Elliott, M.W., eds. Eschatology in Bible \& theology: evangelical essays at the dawn of a new millennium. Downers Grove: InterVarsity. p. 53-69.)

VAN RENSBURG, F.J. 1992. The outline of 1 Peter: a reconsideration. Ekklesiastikos pharos, 74(1):26-41. 
VAN RENSBURG, F.J. 2000. Dekor of konteks? Die verdiskontering van sosiohistoriese gegewens in die interpretasie vir die prediking en pastoraat van 'n Nuwe Testamentteks, geïllustreer aan die hand van die 1 Petrus-brief. Skrif en kerk, 21(3):564-582.

VAN RENSBURG, F.J. 2006. A code of conduct for children of God who suffer unjustly: identity, ethics and ethos in 1 Peter. Beihefte zur Zeitschrift für die neutestamentliche Wissenschaft und die Kunde der älteren Kirche, 141:473-510.

VAN UNNIK, W.C. 1980a. The redemption in 1 Peter i 18-19 and the problem of the first epistle of Peter. (In Barrett, C.K., ed. Sparsa collecta: the collected essays of W.C. van Unnik. Vol. 2. Leiden: Brill. p. 3-82.)

VAN UNNIK, W.C. 1980b. Christianity according to 1 Peter. (In Barrett, C.K., ed. Sparsa collecta: the collected essays of W.C. van Unnik. Vol. 2. Leiden: Brill. p. 11-120.)

VOS, G. 1979. The Pauline eschatology. Grand Rapids: Baker.

\section{Kernbegrippe:}

\section{Petrus}

diskriminasie

eskatologie

vergelding

vindikasie

vreemdelingskap

\section{Key concepts:}

\section{Peter}

alienity

discrimination

eschatology

retaliation

vindication 